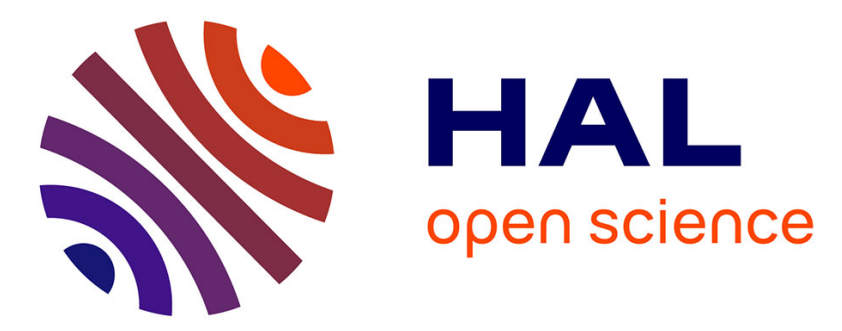

\title{
The redox geodynamics linking basalts and their mantle sources through space and time
}

Fabrice Gaillard, Bruno Scaillet, Michel Pichavant, Giada Iacono-Marziano

\section{To cite this version:}

Fabrice Gaillard, Bruno Scaillet, Michel Pichavant, Giada Iacono-Marziano. The redox geodynamics linking basalts and their mantle sources through space and time. Chemical Geology, 2015, 418, pp.217233. 10.1016/j.chemgeo.2015.07.030 . insu-01187387

\section{HAL Id: insu-01187387 https://hal-insu.archives-ouvertes.fr/insu-01187387}

Submitted on 2 Sep 2015

HAL is a multi-disciplinary open access archive for the deposit and dissemination of scientific research documents, whether they are published or not. The documents may come from teaching and research institutions in France or abroad, or from public or private research centers.
L'archive ouverte pluridisciplinaire HAL, est destinée au dépôt et à la diffusion de documents scientifiques de niveau recherche, publiés ou non, émanant des établissements d'enseignement et de recherche français ou étrangers, des laboratoires publics ou privés.

\section{(ㅇ)(1) $\$$}

Distributed under a Creative Commons Attribution - NonCommercial - NoDerivatives| 4.0 


\title{
The redox geodynamics linking basalts and their mantle sources through space and time.
}

Fabrice Gaillard, Bruno Scaillet, Michel Pichavant, Giada Iacono-Marziano

${ }^{1}$ Université d'Orléans, ISTO, UMR 7327, 45071 Orléans, France.

${ }^{2}$ CNRS, ISTO, UMR 7327, 45071 Orléans, France.

${ }^{3}$ BRGM, ISTO, UMR 7327, BP 36009, 45060 Orléans, France.

\begin{abstract}
The Earth's mantle redox state regulates the fate and transfer of metals by magmatism, buffers the igneous inputs of volcanic gases in the atmosphere and controls the depth of mantle melting. It therefore strongly affects ore forming processes, biogeochemical cycles and deep geodynamic processes. This paper reviews the current knowledge on the redox state of the upper mantle and of magmas produced by mantle melting. The geochemical processes likely to control and modify it through space and time are discussed.

We analyse the link between the redox state of magma and that of their mantle source and we conclude that melts produced in the mantle may well all equilibrate in a narrow range of oxidation state, where the speciation of sulfur in basalts shifts from sulfide to sulfate, that is, FMQ $+1 \pm 1(1 \log$ unit below and above the oxygen fugacity buffered by the assemblage fayalite-magnetite-quartz). Subsequently, degassing and partial crystallization of melts can affect their redox states, producing most of the range of redox states observed on magmas reaching Earth's surface. The asthenosphere sourcing basaltic magmas may therefore be more oxidized than the FMQ-1 value generally assumed.
\end{abstract}

We also discuss redox transfers from the mantle to the atmosphere via volcanic degassing and the backward fluxes via subduction processes of the hydrothermalized oceanic 
lithosphere. Arc-magmas are oxidized (up to FMQ+4) but it is unclear when this feature is acquired since strongly oxidized primary arc-basalts have yet to be found. The oxidizing event may be the assimilation of slab-derived $\mathrm{SO}_{3}$-rich fluids by primary basalt generated by decompression melting in the mantle-wedge.

Overall, subduction must result in a transfer of oxygen from the Earth's surface down to the mantle. This must imply that subduction and its initiation can hardly be the trigger of the great oxidation event at the end of the Archaean. In contrast, the cooling of the Earth's interior through time must have impacted on the redox state of basalts, by decreasing the depth of mantle melting. According to the long-established vertical stratification of the Earth's mantle, ancient primary magmas are therefore likely to have been more reduced (ie. $<$ FMQ-3) than present-day ones. However, geochemical observations on ancient basalts suggest a constant oxidation state since the early Archaean.

We conclude that large uncertainties in the calibration of mineralogical oxygen barometer probably explains why we have difficulties in identifying (i) ancient primary basalts being more reduced than recent ones and (ii) primary basalts from subduction zones being as oxidized as arcs-lavas reaching the surface. Finally, the degree of mantle melting is certainly a key issue for the interpretation of the mantle oxidation state. Extremely oxidized melts, enriched in C-H-S volatile species, produced by very low degrees of mantle melting may be indicative of an Earth's mantle more oxidized than usually considered. 


\section{Introduction: oxygen fugacity and redox transfers}

The redox state of the Earth mantle is of prime interest as it fuels numerous processes such as the behavior and fate of metallic elements involved in ore deposits (Mungall, 2002; Mungall et al., 2006; Ganino et al., 2008; Jenner et al., 2010; Zajacs et al., 2013; Richards, 2015), the depth of partial melting and associated mantle weakening (Rohrbach and Schmidt, 2011; Dasgupta et al., 2013; Stagno et al., 2013; Sifré et al., 2014), and the speciation of magmatic gases that are conveyed to the atmosphere by volcanic degassing (Holland, 2002; Edmonds, 2008; Gaillard et al., 2011; Iacono-Marziano et al., 2012a; De Moor et al., 2013; Yang et al., 2014; Moussallam et al., 2014; Gaillard and Scaillet, 2014). In this paper, we focus on igneous redox processes, leaving aside near surface redox processes intimately tied to life such as $\mathrm{H}_{2}\left( \pm \mathrm{CH}_{4}\right)$ production associated with serpentinisation of oceanic crust (Sleep et al., 2011; Russell et al., 2013) or sulfate reduction in sediments (Lyons and Gill, 2010).

Identifying variations in mantle redox state both in time and space and capturing the parameters that control redox state inside the Earth is the kernel of a wide and active debate in Earth and planetary sciences (Ballhaus et al., 1991; O’Neill et al., 1993; Ballhaus and Frost, 1994; Canil, 1997; Delano, 2001; Canil, 2002; McCammon 2005; Frost and McCammon, 2008; Hirschmann, 2009; Kelley and Cottrell, 2009; Scaillet and Gaillard, 2011; Trail et al., 2011; Foley, 2012; Lee et al., 2012; Keller and Schoene, 2012; Bali et al., 2013; Yang et al., 2014). The second issue is about whether the redox state of basalts and associated volcanic gases reflects their mantle source regions (Carmichael and Ghiorso, 1986; Carmichael, 1991; Lee et al., 2005; Mallmann and O’Neill, 2009; Kelley and Cottrell., 2012; Moussallam et al., 2014), and if not, what are the processes likely to change magma redox state upon ascent to the Earth's surface (e.g., Carmichael and Ghiorso, 1986; Carmichael and Ghiorso, 1990; Gaillard et al., 2011; Kelley and Cottrell, 2012; Iacono-Marziano et al., 2012b; Moussallam et al., 2014). So far, iron, owing to its high abundance and variable oxidation state, has been 
identified as the main redox buffer in mantle rocks and mantle-derived magmas (Wilke, 2005; Behrens and Gaillard, 2006; Rorhbach et al., 2007; Frost and McCammon, 2008). However, volatile elements such as hydrogen, carbon and sulfur have tremendously variable oxidation states (Behrens and Gaillard, 2006; Jugo, 2009; Rohrbach and Schmidt, 2011; Evans, 2012), and are therefore likely to locally affect, and even buffer, mantle and magma redox states.

The redox state of mineral, rocks, melts and fluids is conventionally related to oxygen fugacity, $\mathrm{fO}_{2}$, a thermodynamic parameter that gauges the availability of oxygen in a given system. High $\mathrm{fO}_{2}$ characterizes oxidized systems (Frost, 1991). Several processes are likely to modify the $\mathrm{fO}_{2}$ of rocks. The most intuitive is via a change in the oxygen / cation ratio of the rock, occurring in an open system, in which oxygen is truly gained or lost producing either an increase or a decrease in the oxygen / cation ratio of the system (Cooper et al., 1996; Behrens and Gaillard, 2006; Evans, 2008). A typical example is a fluid or melt interacting with a rock and generating reactions that can oxidize or reduce the pervaded system by rising or decreasing its oxygen / cation ratio. Such phenomena are documented in all geodynamic settings and are usually termed fluid-rock interactions as observed in mantle metasomatism (Menzies, 1983; Woodland et al., 1996; Coltorti et al., 1999; McCammon et al., 2001; O’Reilly and Griffin, 2012) and hydrothermal processes (Honnorez, 2003; Evans, 2008).

Variations in $\mathrm{fO}_{2}$ also happen in closed systems when a phase change occurs. Melting, or mineralogical transitions are typically able to modify the $\mathrm{fO}_{2}$ of a rock (and the oxygen / cation ratios of the individual phases), while degassing and crystallization can modify the $\mathrm{fO}_{2}$ of a melt, even in absence of change of the oxygen / cation ratio of the bulk system (Carmichael and Ghiorso, 1986). An example is the decompression of graphite-saturated systems inducing graphite volatilization and the reduction of the system (Sato, 1978; IaconoMarziano et al., 2012b; Shirayev and Gaillard, 2014). Yet, redox changes in a closed system may also occur via the modifications of properties of one or several phases constituting the 
rocks without phase transitions. Upon a change in pressure or temperature, the ability of a phase to preferentially take a reduced or oxidized species can vary. This in turn induces a change in oxygen availability in the system, which translates into a change in the equilibrium $\mathrm{fO}_{2}$ (i.e. the $\mathrm{fO}_{2}$ of the rock-melt-fluid involved in the system) whereas the oxygen / cation ratio of the bulk system remains unchanged. For instance the decompression of sulfur-bearing volcanic gases drives the system toward more reducing conditions (Burgisser and Scaillet, 2007; Gaillard et al., 2011; Kelley and Cottrell, 2012; Moussallam et al., 2014). Another example is the decompression of garnet-bearing peridotites leading to increasingly oxidizing conditions (Woodland et al., 2003; Rohrbach et al., 2007; Frost and McCammon, 2008; Rohrbach and Schmidt, 2011; Stagno et al., 2013; see section 3.2.).

Because the oxygen fugacity of systems with a given oxygen / cation ratio changes with changing pressure and temperature, $\mathrm{fO}_{2}$ is conventionally expressed relatively to that buffered by a relevant mineral assemblage. The $\mathrm{fO}_{2}$ of mantle rocks is usually calculated in log-units relative to that of the fayalite-magnetite-quartz redox buffer, FMQ (Frost, 1991). The $\mathrm{fO}_{2}$ of most mantle rocks and magmas is conveniently over ca. 2 log-unit accross the FMQ buffer (Carmichael, 1991; Frost and McCamon 2008; Foley, 2011) but secular changes as well as regional controls significantly extend this range (Scaillet and Gaillard, 2011; Iacono-Marziano et al., 2012b).

This paper reviews the current knowledge on mantle $\mathrm{fO}_{2}$, (i) how it controls the $\mathrm{fO}_{2}$ of mantle-derived magmas and impacts on volcanic gas compositions, (ii) how it varies with depth and (iii) how it may be modified by global geodynamics. The main purpose is to capture the processes that may have induced secular variations in redox state of the mantle and related magmas. Whenever possible, the link with the redox evolution of the atmosphere is emphasized. 


\section{The Early redox story of the Earth's mantle and its magmatism.}

\subsection{Magma ocean redox geodynamics: internal- and self-oxidation.}

It is well accepted that temperature was hot enough during planetary accretion, so as to permit large scale melting (magma oceans), and that conditions were reducing enough to trigger Fe-metal saturation from a molten silicate (e.g., Walter and Tronnes, 2004; Wood et al., 2006), that is, ca. 6 log-units below the present-day estimated/observed lithospheric mantle $\mathrm{fO}_{2}$. It is believed that several magma ocean events occurred during planet growth, from the earliest planetesimal stage to the ultimate planet-size, stage, including the Moon forming event (O’Neill, 1991; Greenwood et al., 2005). The temperature and depth of the magma ocean, hence the pressure at the bottom of the magma ocean, both increase with planet size (Wood et al., 2006; Rubie et al., 2011). For various reasons that we expose below, it is generally accepted that such an increase in pressure and temperature triggers/is accompanied by a progressive shift from strongly reduced to moderately reducing conditions. The enstatite chondrite model of Javoy et al (1995) has recently been rejuvenated by several workers (Wood et al., 2006; Javoy et al., 2010; Ricolleau et al., 2011; Rubie et al., 2011), based on the observation that laboratory-based metal-silicate partitioning coefficients better explain the depletion level of various chemical elements in the Earth's mantle (relative to their chondritic parents) if oxygen fugacity increased during accretion from ca. IW-5 to IW-2; the latter value has been inferred from the fairly uniform $\mathrm{FeO}$ content of the Earth's mantle requiring an $\mathrm{fO}_{2}$ at IW-2 at Fe-metal saturation (Wood et al., 2006; Frost et al., 2008; Gaillard and Scaillet, 
2009). An increase in $\mathrm{fO}_{2}$ can be justified by the fact that at high $\mathrm{P}$ and high $\mathrm{T}$, Si becomes soluble in metal according to the following reaction:

$$
\mathrm{SiO}_{2}{ }^{\text {silicate }}+2 \mathrm{Fe}^{\text {metal }} \leftrightarrow 2 \mathrm{FeO}^{\text {silicate }}+\mathrm{Si}^{\text {metal }}
$$

Recent modelling indicates that between 2 and $8 \mathrm{wt} \% \mathrm{Si}$ can be incorporated into the forming core (Ricolleau et al., 2011), which translates into a significant gain in FeO content of the coexisting silicate melt (at the base of the magma ocean). As long as metal and silicate melt coexist, the oxygen fugacity of the magma ocean is controlled by the following fundamental reaction:

$$
\mathrm{Fe}^{\text {metal }}+1 / 2 \mathrm{O}_{2} \leftrightarrow \mathrm{FeO}^{\text {silicate }}
$$

Equilibrium (2) implies that any increase in the $\mathrm{FeO}$ content of the silicate melt is accompanied by an increase in $\mathrm{fO}_{2}$, which therefore affects partitioning of all elements between the silicate mantle and the metal core. The Enstatite chondrite model of Javoy et al (1995) implies an initial oxygen fugacity 5 orders of magnitude lower than that imposed by the iron - wustite redox buffer (Fig.1). Under such conditions, equilibrium (2) predicts that no $\mathrm{FeO}$ would be dissolved in the magma ocean. Silicon dissolution in the core following eq. (1) enables an increase in the $\mathrm{FeO}$ content of the coexisting silicate melt; on Earth, the Enstatite chondrite model predicts that equilibrium (1) was shifted (by high P-T conditions) rightward until $\mathrm{FeO}^{\text {mantle }}$ reached a value of $8 \mathrm{wt} \%$ : this is the internal-oxidation (Fig. 1) although this terms has also been used to define the oxidation process exposed below (See Williams et al., 2012). Accepting the latter value as the average mantle $\mathrm{FeO}$ concentration thus essentially fixes at IW-2 the $\mathrm{fO}_{2}$ of the last core-mantle equilibration.

An additional driving force for the oxidation (usually called self-oxidation) of the early Earth's mantle is perovskite crystallization (in the lower mantle) which goes along with a disproportionation reaction: 


$$
3 \mathrm{Fe}^{\mathrm{II}} \mathrm{O}=>\mathrm{Fe}^{0}+2 \mathrm{Fe}^{\mathrm{III}} \mathrm{O} 1.5
$$

Upon crystallization, perovskite can take a significant portion of ferric iron (O’Neill et al., 1993; McCammon, 1997; Frost et al., 2004; Frost et al., 2008), a property that contrasts with the other silicate minerals that are stable at lower pressure such as olivine and garnet. Therefore, perovskite crystallizing from a bulk composition being dominated by ferrous iron would trigger the above reaction (3), incorporating ferric iron in its structure and leaving metal $\mathrm{Fe}$ as an interstitial phase. Metal $\mathrm{Fe}$ must have migrated toward the forming core probably via the sinking of metal-rich diapirs (e.g., Rubie et al., 2003; Yoshino et al., 2003; Takafuji et al., 2004; Frost et al., 2008), leaving a silicate lower mantle that is significantly more oxidized. Subsequent convective exchanges must have transferred $\mathrm{Fe}^{3+}$-rich rocks in the upper mantle. This self-oxidation process (Fig. 1), may well have contributed to the progressive oxidation of the silicate Earth during accretion, at least during its ultimate stages, and may have also been the trigger of the Great Mantle Oxidation event (Delano, 2001; Scaillet and Gaillard, 2011; Williams et al., 2012), which is a major shift in redox conditions of the Earth's mantle, passing from IW-2 just after the core-mantle separation, to FMQ+0.5/-2 (IW+3/+4.5), as recorded by the oldest mantle rocks (Canil, 1997; Delano, 2001; Canil, 2002; $\mathrm{Li}$ and Lee, 2004). Occurrence of oxidized $4.4 \mathrm{Ga}$ old zircons of inferred mantle provenance (Trail et al., 2011; fig. 1) suggests that this redox transition of 6 log-units in $\mathrm{fO}_{2}$ has most likely been rapid (see also the isotopic evidence in Williams et al., 2012). This shift also may have been also captured in the crustal zircons that have crystallized during the Hadean (Yang et al., 2014, see section 3 below). The present-day mantle displays a range of $\mathrm{fO}_{2}$ similar to that prevailing during the early Archean, that is, FMQ \pm 1 . The secular redox constancy since the Archean indicates a probable mantle oxygen buffering, but the nature of this buffer and whether one or several buffers act in the mantle remain undefined. The propensity of garnet to uptake ferric iron (Rohrbach et al., 2007; Rohrbach et al., 2011) suggests that it may have 
played such a role, yet it is also likely that carbon controlled the mantle redox state (Stagno et al., 2013). Processes that may have governed or delayed the mantle great oxidation event and its consequences for the redox state of magma and of volcanic gases are further discussed below.

\subsection{Volcanic gases and basalts, hadean to present.}

The abundances of volatile species in the $\mathrm{C}-\mathrm{O}-\mathrm{H}-\mathrm{S}$ system, in equilibrium with a basaltic melt at atmospheric pressure, are shown as a function of oxygen fugacity in figure 2 (see Gaillard and Scaillet 2009 for methods). The calculation simulates the gas composition in equilibrium with basaltic melts at atmospheric pressure; the system, basalt + gas, has a bulk S, $\mathrm{H}$ and $\mathrm{C}$ contents that are broadly similar to those of a Mid-Ocean-Ridge-Basalt considering the range of concentrations reported in Jambon, (1994), Dixon et al., (1997), Cartigny et al. (2008), Jenner and O’Neill (2012), Marty (2012) (i.e. 1500 ppm S, 1500 ppm $\mathrm{H}_{2} \mathrm{O}, 900$ ppm $\left.\mathrm{CO}_{2}\right)$. Gas speciation in the case of volatile-rich basalts $\left(5000 \mathrm{ppm} \mathrm{H}_{2} \mathrm{O}, 5000\right.$ ppm $\left.\mathrm{CO}_{2}\right)$ is also shown (Fig. 2b), in order to account for the range of $\mathrm{CO}_{2}$ estimates (and $\mathrm{H}_{2} \mathrm{O}$ to a lesser extent) for the oceanic mantle in general (see Dixon et al., 1997; Cartigny et al., 2008; Dasgupta and Hirschmann, 2010; Helo et al., 2011; Marty, 2012). At 1 bar, the C and $\mathrm{H}$ of the system mostly partition into the gas, whereas $\mathrm{S}$ partitioning depends on $\mathrm{fO}_{2}$ as described in the next paragraph. ). At 1 bar, the $\mathrm{C}$ and $\mathrm{H}$ of the system mostly partition into the gas, whereas $\mathrm{S}$ partitioning strongly depends on $\mathrm{fO}_{2}$. At $\mathrm{fO}_{2}$ higher than $\mathrm{FMQ}$, the gas speciation is unchanged and dominated by $\mathrm{H}_{2} \mathrm{O}, \mathrm{SO}_{2}$ and $\mathrm{CO}_{2}$. At more reducing conditions, the gas speciation is tightly controlled by $\mathrm{fO}_{2}$ : the speciation shift occurs between FMQ-3 and FMQ0.5, depending on the considered species. Sulfur occurs mostly as $\mathrm{SO}_{2}$ at and above FMQ, predominantly as $\mathrm{S}_{2}$ at around FMQ-1.5, and mainly as $\mathrm{H}_{2} \mathrm{~S}$ at or below FMQ-3. For carbon, the cross over between $\mathrm{CO}_{2}$ and $\mathrm{CO}$ occurs at FMQ-2.5. For hydrogen, the $\mathrm{H}_{2} \mathrm{O}$ to $\mathrm{H}_{2}$ transition occurs at FMQ-3.5. As shown by the b and c panels in Figure 2, these redox 
transitions in gas speciation occur at similar $\mathrm{fO}_{2}$ regardless of the depleted or enriched character of the basalt. The $\mathrm{fO}_{2}$-dependance of gas speciation is shown here at $1300^{\circ} \mathrm{C}$, a temperature that we consider representative of basalt eruption on Earth. The solubility relationships are weakly temperature dependent, though the $\mathrm{SO}_{2} / \mathrm{H}_{2} \mathrm{~S}$ ratio in the gas is a strong function of temperature (and pressure as discussed below and see Gaillard et al. (2011)). Hotter conditions will favour $\mathrm{SO}_{2}$ (even at conditions more reducing than FMQ), whereas cooler gas will augment the $\mathrm{fO}_{2}$ domain where $\mathrm{H}_{2} \mathrm{~S}$ dominates. This has important implications that have received so far little attention from the community: for example, a mafic magma produced at $\mathrm{fO}_{2}$ close to FMQ-0.5, like many erupting basalts, will degas mainly $\mathrm{SO}_{2}$ if hot $\left(1300^{\circ} \mathrm{C}\right.$ or more) or yield as much as $20 \%$ of its sulfur as $\mathrm{H}_{2} \mathrm{~S}$ if cold (ie. $1100-1200^{\circ} \mathrm{C}$ ); consequently, a magmatic system having its $\mathrm{fO}_{2}$ buffered by the speciation of sulfur in its fluid phase $\left(\mathrm{SO}_{2} / \mathrm{H}_{2} \mathrm{~S}\right)$ will present increasing $\mathrm{fO}_{2}$ upon cooling. Below, we will discuss how changes in pressure can also affect the $\mathrm{SO}_{2} / \mathrm{H}_{2} \mathrm{~S}$ ratio and can therefore change magma $\mathrm{fO}_{2}$.

A remarkable feature that is worth stressing out is the strong $\mathrm{fO}_{2}$ dependence of gas-melt partitioning for sulfur, as illustrated in Fig. 2. Since the bulk sulfur content is fixed (1500 ppm $\mathrm{S}$ ), the fact that the melt sulfur content (dashed curves in fig.2) decreases as $\mathrm{fO}_{2}$ increases indicates that sulfur is not volatile at low $\mathrm{fO}_{2}$ whilst it becomes increasingly volatile as $\mathrm{fO}_{2}$ increases. At $\mathrm{fO}_{2}$ conditions close to $\mathrm{FMQ}$, virtually all sulfur is outgassed. As shown by Gaillard and Scaillet (2009) and Gaillard et al. (2013), this implies that reduced magmas, such as during the magma ocean stage of any planet or planetary embryo, are unable to degas sulfur species in any significant abundance; sulfur outgassing from magmas is only possible if their $\mathrm{fO}_{2}$ is sufficiently high (>FMQ-2. A similar trend of sulfur gas-melt partitioning is observed for $\mathrm{H}_{2} \mathrm{O}-\mathrm{CO}_{2}$ enriched basalts (Fig 2), but overall, sulfur tends to be more volatile. This essentially reflects a mass balance effect, i.e. $\mathrm{CO}_{2}$ and $\mathrm{H}_{2} \mathrm{O}$ increase the amount of fluid 
phase and more efficiently extracts sulfur from the melt at constant gas-melt partition coefficient for sulfur. In summary, in addition to controlling the sulfur speciation in the gas phase, $\mathrm{fO}_{2}$ also controls the extent of sulfur outgassing, as observed in silicic systems (Scaillet et al., 1998).

Several studies have argued that secular variations in mantle $\mathrm{fO}_{2}$ may have occurred (e.g., Kasting et al., 1993; Foley, 2012) during the Archaean and that such variations would translate into increasing $\mathrm{fO}_{2}$ of basalts. Such a shift in mantle redox state could have triggered, or at least played a role, in the transition from a moderately reduced to an oxygenated atmosphere at $2.4 \mathrm{Ga}$ (Holland, 2002). An increase in the $\mathrm{SO}_{2} / \mathrm{H}_{2} \mathrm{~S}$ ratio of volcanic gases, related to such increasing magma $\mathrm{fO}_{2}$, may also explain the sulfur mass independent fractionation recorded in the late Archean sediments just before the oxygenation of the atmosphere (Lyons and Gill, 2009; Halevy et al., 2010). Figure 2 indeed indicates that a change from $100 \% \mathrm{H}_{2} \mathrm{~S}$ to $100 \% \mathrm{SO}_{2}$ is predicted to occur in response to an increase of $3 \mathrm{log}$ units in basalt $\mathrm{fO}_{2}$. Noteworthy, the total sulfur outgassed by basalts would also greatly change in response to such a $\mathrm{fO}_{2}$ increase: at FMQ-3 only $10 \%$ of the magmatic sulfur is outgassed, whereas at FMQ, nearly $100 \%$ is degassed. A progressive increase in $\mathrm{fO}_{2}$ of basalts through time may therefore have introduced more sulfur into the atmosphere and increased its $\mathrm{SO}_{2} / \mathrm{H}_{2} \mathrm{~S}$ ratio.

Gaillard et al. (2011), however, indicated that a change in the redox state of the source region of basalts is not necessarily needed since a change in the pressure of degassing (e.g. submarine versus subaerial volcanism) exerts a prime control on the efficiency of sulfur outgassing and on its redox state in the gas. A transition from submarine-dominated to subaerial-dominated volcanic degassing may generate the increase in $\mathrm{SO}_{2} / \mathrm{H}_{2} \mathrm{~S}$ ratio demanded by sulfur mass independent fractionation preceding the great oxidation event. Subaerial degassing would also inject more sulfur directly into the atmosphere. The 
emergence of continental surfaces which has accompanied the peak in crustal growth documented at the end of the Archean is consistent with an increasing proportion of subaerial volcanism (Kump and Barley, 2007). Following Gaillard et al. (2011), we stress that a change in the average pressure of magmatic degassing might also have occurred if the planetary intrusive/extrusive ratio changed: an increasing proportion of extrusive rocks forming through the Archaean may well have produced an increase in the $\mathrm{SO}_{2} / \mathrm{H}_{2} \mathrm{~S}$ ratio in magmatic gases and enhanced the amount of sulfur outgassed. The driving force for such a change in the intrusive/extrusive ratio remains hypothetical but it may be related to the viscosity of the Archaean crust (Yang et al., 2014) evolving in response to the cooling of the underlying mantle (Herzberg et al., 2010). Altogether, we wish to emphazise that the hypothesis of Gaillard et al (2011) does not require secular variations in mantle oxygen fugacity in order to trigger a planetary change in the oxidation state of volcanic gases, but it does not exclude it.

Evidence against a change in $\mathrm{fO}_{2}$ of the mantle and derived-basalts during the archean has been first put forward by Canil (1997) who showed that, in Archean Komatiites, vanadium partitioning between melt and olivine crystals points to $\mathrm{fO}_{2}$ around FMQ. Subsequent work have confirmed such an observation and generalized it to other types of Archean basalts. Li and Lee (2004) used vanadium partitioning normalized to that of scandium, to remove the effect of magmatic differentiation on oxygen fugacity: V/Sc ratios in basalts should therefore reflect the redox state of their mantle source. Compiling V/Sc ratios of a large number of archean basalts, Li and Lee (2004) have shown that they are indistinguishable from the present-day MORBs, indicating an Archaean mantle, source of Archaean basalts (up to $3.5 \mathrm{Ga}$ ), at around FMQ. The constancy of mantle and basalt $\mathrm{fO}_{2}$ is also suggested by the $\mathrm{Cr}$ content of spinel-saturated basalts back to 3.9 Ga (Delano, 2001). However, it is unclear whether our sample collection of the Archean is not biased since the Archean basalts that have been so far analysed are coming from the continental mantle (Foley, 
2012). The possibility that the present-day continental mantle is more oxidized that the oceanic one has long been proposed (Wood et al., 1990), but is still debated (Frost and McCamon, 2008; Foley, 2012).

In conclusion, if we accept that the Archean mantle was as oxidized as the present-day mantle, the process that is buffering the $\mathrm{fO}_{2}$ during mantle melting and why it has remained unchanged since the formation of the earliest rock so far sampled, remain unexplained.

\subsection{Volcanic gases and felsic melts during the hadean}

The most ancient estimate of magmatic $\mathrm{fO}_{2}$ on Earth comes from $>4.3 \mathrm{Ga}$ old zircons (Trail et al., 2011) some of which are supposed to have crystallized from hydrous granitic melts (Watson and Harrison, 2005; Hopkins et al., 2010). The cerium content in these minerals, which has been shown experimentally to depend on $\mathrm{fO}_{2}$ as shown experimentally (Trail et al., 2011; Burnham and Berry, 2012), is well-matched by redox conditions in the range $\mathrm{FMQ} \pm 2$. In detail and quite surprisingly, zircons with mantle-like oxygen isotope compositions indicate $\mathrm{fO}_{2}$ higher than crustal-like zircons (Trail et al., 2011; Yang et al., 2014). Though large error bars are associated to these estimates (Burnham and Berry, 2012), the emerging picture is that the Earth's mantle evolved from a Fe-metal saturated magma ocean stage, with $\mathrm{fO}_{2}$ as reduced as FMQ-6, to a nearly solid mantle with $\mathrm{fO}_{2}$ similar to FMQ, within 200 million years or less (Fig.1). In a recent survey, Yang et al. (2014) reviewed a large database of Hadean zircons and suggested that crustal zircons of Hadean ages have in fact captured the missing oxidation step between 4.4 and $3.8 \mathrm{Ga}$, while mantle zircons recorded a mantle that was already oxidized. The cerium content of crustal zircons indeed indicates a $\mathrm{fO}_{2}$ increasing from a Fe-metal saturated crust, that is $<\mathrm{IW}$, to a modern like redox state, close to FMQ. The explanation advanced by Yang et al. (2014) involves the late veneer, that is, a supply of chondritic material to the Earth's mantle after the core-mantle chemical 
separation had occurred. The late veneer is also suggested as the main supplier of $\mathrm{C}-\mathrm{H}-\mathrm{N}$ and noble gases to the Earth mantle (Marty, 2012). The chondritic material constituting the late veneer being rich in reduced carbon and hydrogen, it must have affected the redox state of the shallow crust/mantle by, for example, shifting it toward more reducing conditions if the mantle was already oxidized as suggested by Trail et al (2011). Furthermore, the magnitude of the reducing shift caused by the late veneer addition decreases with pressure, being trivial at mantle conditions (Yang et al., 2014). The picture of a reduced Hadean crust (resulting from the late veneer chondritic material) overlying a more oxidised mantle (owing to the selfoxidizing processes described above) challenges the conventional wisdom on the redox controls in the earliest mantle and may also have implications on the vertical redox stratification of the magma ocean during the accretion stages (see for example Hirschmann, 2012). In particular, if the hadean zircons grew from hydrous (ca $3 \mathrm{wt} \% \mathrm{H}_{2} \mathrm{O}$ ) low temperature granitic melts as suggested by its mineral inclusions (Hopkins et al., 2010), the magmatic gas produced by such a system is rich in $\mathrm{CH}_{4}$ (Yang et al., 2014). The conjunction of low temperature, high water activity and low $\mathrm{fO}_{2}$ predicted for the Hadean felsic melts (note, however, that low $\mathrm{fO}_{2}$ tends to limit water activity see Schmidt et al., 1997) trigger magmatic gas compositions that differ significantly from those basaltic (Fig. 2), which are dominated by $\mathrm{CO}$ and $\mathrm{H}_{2}$ species at low $\mathrm{fO}_{2}$. The Hadean melts must have degassed a significant fraction of methane $\mathrm{CH}_{4}$ as the following equilibrium is shifted rightward as $\mathrm{P}$ increases or $\mathrm{T}$ decreases:

$$
\mathrm{CO}+3 \mathrm{H}_{2} \leftrightarrow \mathrm{CH}_{4}+\mathrm{H}_{2} \mathrm{O}
$$

\section{Mafic melts $\quad$ Felsic melts}

Low temperature (Fig. 3A) and moderately high pressure (Fig. 3B) both favour methane production during the degassing of felsic Hadean melts. The $\mathrm{fO}_{2}$ evolution of these melts with variations in $\mathrm{P}$ and $\mathrm{T}$ is driven by graphite-saturation (Fig. 3A; see Iacono-Marziano et al., 
2012b; Shirayev and Gaillard, 2014) but is also influenced by the displacement of eq. (4) which is changing the $\mathrm{H}_{2} / \mathrm{H}_{2} \mathrm{O}$ ratio. To conclude, mafic or ultramafic melts prevailing during the Hadean ages were certainly not as rich in water as the felsic melts from which zircons grew and they were much hotter (by $300-400^{\circ} \mathrm{C}$ ); this implies that they have injected $\mathrm{CO}$ and $\mathrm{H}_{2}$ gases in the earliest atmosphere, that is, at $4.5 \mathrm{Ga}$; mantle derived mafic melts rapidly shifted their emissions toward $\mathrm{CO}_{2}-\mathrm{H}_{2} \mathrm{O}-\mathrm{SO}_{2}$ gas mixtures at $4.3 \mathrm{Ga}$ (fig.1-2); in contrast, the felsic Hadean magmas produced $\mathrm{CH}_{4}$ and $\mathrm{H}_{2} \mathrm{O}$ during most of the Hadean (Yang et al., 2014).

\section{Regional control on magmatic oxygen fugacities}

The redox state of basaltic melts reaching the surface is inherited from that of their mantle source and maybe affected by late shallower processes such as assimilation, degassing or crystallization (Mathez, 1984; Carmichael, 1991; Burgisser and Scaillet, 2007; Cottrell and Kelley, 2011; Gaillard et al 2011; Kelley and Cottrell, 2012; Iacono-Marziano et al., 2012b). Overall, the range of $\mathrm{fO}_{2}$ reported for terrestrial basalts ranges from FMQ-6 to FMQ+4. The lowermost value corresponds to the Fe-metal bearing basalts (found at the Siberian Trapps and other sites) that were affected by assimilation of carbonaceous rocks (coal and oils, Iacono-Marziano et al., 2012b). In most common and modern basalts, however, oxygen fugacities range from FMQ-2 to $\mathrm{FMQ}+3$. The upper $\mathrm{fO}_{2}$ range is found in arc-related lavas (Pichavant and McDonald, 2007; Kelley and Cottrell, 2012) and alkali-rich mafic melts (Carmichael, 1991; Dixon et al., 1997), the latter being typically produced at small degree of mantle melting; although alkali-rich melts tend to have high amounts of ferric iron even at moderate $\mathrm{fO}_{2}$ (Gaillard et al., 2001), the Kress and Carmichael (1991) equation can account reasonably well for their $\mathrm{fO}_{2}$-ferric/ferrous ratio relationships (Moussallam et al., 2014).

\subsection{Magmatic production from up-welling mantle regions}


Mid-ocean ridge lavas have long been assumed to be the most reduced magmas existing on Earth. The first global estimates of MORB redox state was based on measurements by a wet chemical method of the ferric-ferrous ratios of basaltic glasses quenched in deep sea (Christie et al., 1986), which yielded an average $\mathrm{Fe}^{3+} / \mathrm{Fe}_{\text {tot }}$ ratio of $0.07( \pm 0.01)$ corresponding to an average $\mathrm{fO}_{2}$ of FMQ-1.2. This first $\mathrm{Fe}^{3+} / \mathrm{Fe}_{\text {tot }}$ estimate was revised upward by Bezos and Humler (2005), using a broadly similar methodology, who proposed an average $\mathrm{Fe}^{3+} / \mathrm{Fe}_{\text {tot }}$ ratio for MORBs higher $(0.12 \pm 0.02)$, corresponding to an $\left.f_{2} \sim \mathrm{FMQ}-0.4\right)$. Recently, using XANES spectroscopy, Cottrell and Kelley $(2011 ; 2013)$ have shown glassy MORB Fe ${ }^{3+} / \mathrm{Fe}_{\text {tot }}$ ratio to be in the range $0.16-0.18$, corresponding to $\mathrm{fO}_{2}$ between FMQ and FMQ+1. The significantly highest $\mathrm{Fe}^{3+} / \mathrm{Fe}_{\text {tot }}$ ratio is explained by sulphur ions dissolved in the glass that tend to increase the amount of ferrous iron titrated by wet chemical methods; this analytical bias seems to be avoided if XANES spectroscopy is used (Cottrell and Kelley, 2011). Independent estimates of MORBs $\mathrm{fO}_{2}$ are given by Mallmann and O'Neill $(2009 ; 2013)$ based on $\mathrm{V} / \mathrm{Sc}$ and $\mathrm{V} / \mathrm{Ga}$ of primitive MORBs (bulk rock), which provide clues on the $\mathrm{fO}_{2}$ during melt extraction from the mantle (about $10 \%$ partial melting). The obtained $\mathrm{fO}_{2}$ is in the range FMQ-1/FMQ, which is remarkably similar to the Bezos and Humler (2005) estimate based on MORB $\mathrm{Fe}^{3+} / \mathrm{Fe}_{\text {tot }}$ ratios analysed by wet chemistry, though the latter seems to yield underestimated $\mathrm{Fe}^{3+} / \mathrm{Fe}_{\text {tot }}$ ratio. Self-oxidation processes (Carmichael and Ghiorso, 1986) by selective uptake of ferrous iron during olivine ( \pm orthopyroxene) fractionation at shallow depth may however explain the increase in the $\mathrm{Fe}^{3+} / \mathrm{Fe}_{\text {tot }}$ ratio up to $0.16-0.18$ (Cottrell and Kelley, 2011).

An important implication of the reappraisal of MORBs redox state is that their source region, that is, broadly speaking, the depleted mantle (Marty, 2012), is not oxygen depleted: using laboratory-based partition coefficient for ferric iron during mantle melting (Mallmann and O’Neill, 2009), Cottrell and Kelley (2013) estimated that 0.3 wt\% of $\mathrm{Fe}_{2} \mathrm{O}_{3}$ must be 
present in the mantle source region producing MORBs, which is similar to the estimates for the undepleted mantle (Canil et al., 1994) based on direct measurements on mantle xenoliths.

It is unclear whether Oceanic Island basalts (OIB) are more oxidized than MORBs. The chemical enrichment in incompatible elements for OIB may call for oxygen enrichment at their source but the relationship between source enrichment (in incompatible elements) and oxygen enrichment established in Cottrell and Kelley (2013) for MORBs indicate the opposite: the more enriched, the more reduced. Mallmann and O'Neill (2009) concluded that the $\mathrm{fO}_{2}$ of OIB source regions can hardly be distinguished from that of MORB based on V/Sc and $\mathrm{V} / \mathrm{Ga}$ ratios, but uncertainties are large. A similar conclusion has been suggested by Kelley and Cottrell (2011) based on $\mathrm{Fe}^{3+} / \mathrm{Fe}_{\text {tot }}$ measured in glasses from OIB, though a few samples slightly more oxidized than MORBs are briefly mentioned. Uenver-Thiele et al (2014) established that the source regions of the Massif Central magmatic province is significantly oxidized, with fO2 of mantle xenolith indicating metasomatism by an oxidized melt (>FMQ). At Reunion Island, Pichavant et al (2014) reported $\mathrm{fO}_{2}$ estimates using a variety of methods based on melt ferric-ferrous ratio and crystal-liquid equilibria. The average $\mathrm{fO}_{2}$ values, $\mathrm{FMQ}+0.2$, is similar to MORBs, but higher values have also been obtained, up to $\mathrm{FMQ}+1.4$ (the latter being based on $\mathrm{Fe}^{3+} / \mathrm{Fe}_{\text {tot }}$ in glass). At Hawaii, magma redox states seem to decrease with degree of mantle melting, from FMQ+0.7 for alkali-rich basalt to FMQ- 0.8 for those alkali-poor (Dixon et al., 1997). Careful analyses of degassed lavas reveal their reduced character, i.e. FMQ-1 (Roeder et al., 2003), compared to the average redox state of volcanic gases (FMQ+0.3, Gerlach, 1993), suggesting that sulphur degassing could reduce the magma as discussed in section 2.2. In detail, however, not all S-degassed lavas at Hawaii obey such a trend (Rhodes and Vollinger, 2005), some S-rich lavas being among the most reduced ones (FMQ-1.8), possibly implying that the redox state of the mantle source of Hawaiian basalts may vary at a regional scale. 
In summary, magmas formed in up-welling regions, by decompression melting, have $\mathrm{fO}_{2}$ close to FMQ. Analyses of mantle xenoliths brought to the surface by such magmas have yielded a range of $\mathrm{fO}_{2}$ which have been compiled by Foley (2012): the oceanic and continental lithosphere xenoliths equilibrated at FMQ-0.7/-1, very similar to the riftinfluenced mantle (FMQ-0.4); xenoliths from within plate oceanic settings are significantly more oxidized (FMQ+0.6) which, along with the rare findings of high $\mathrm{fO}_{2}$ conditions in OIB basalts (see above), hint at more oxidized source regions (but see Rhodes and Vollinger, 2005). This slightly more oxidized nature of the intraplate mantle can be related to metasomatic events (Woodland et al., 1996; McCammon et al., 2001; Coltorti et al., 1999; Creighton et al., 2009), which involve infiltration-reaction of carbon dioxide and water-rich low degree melts prior to basalt production. The involvement of such low degree melts in the source regions of MORBs has been also suggested (Wallace and Green, 1988; Gaillard et al., 2008; Dasgupta et al., 2013), including for the formation of the enriched MORBs (E-MORBs) variety. In general, however, existing attempts at capturing these enrichment-oxidation relationships have been elusive. In fact the opposite of expectations has been found from mantle xenoliths (Woodland et al., 1996; Coltorti et al., 1998; McCammon et al., 2001; Creighton et al., 2009; Uenver-Thiele et al., 2014), that is, enriched mantle seems to be more reduced (Cottrell and Kelley, 2013).

\subsection{Redox profile in the sub-solidus Mantle}

The garnet-olivine-pyroxene assemblage in mantle rocks allows equilibrium oxygen fugacity to be calculated from the composition of coexisting minerals.

$$
\begin{aligned}
& 2 \mathrm{Fe}_{3} \mathrm{Fe}_{2}{ }^{3+} \mathrm{Si}_{3} \mathrm{O}_{12} \leftrightarrow \quad 4 \mathrm{Fe}_{2} \mathrm{SiO}_{4} \quad+2 \mathrm{FeSiO}_{3} \quad+\mathrm{O}_{2} \\
& \text { Skiagite (Garnet) Fayalite (Olivine) Enstatite(OPX) } \\
& \mathrm{fO}_{2}=\mathrm{K}_{(\mathrm{P}, \mathrm{T})} \times \mathrm{a}^{2} \text { Skiagite } \times\left(\mathrm{a}^{4} \text { Fayalite } \times \mathrm{a}^{2} \text { Entstatite }\right)
\end{aligned}
$$


Provided that the thermodynamic constant, $\mathrm{K}_{(\mathrm{P}, \mathrm{T})}$, and the activity-composition relationships for skiagite in garnet, fayalite in olivine, and enstatite in orthopyoxyene are known, then oxygen fugacity can be calculated. Gudmunsson and Wood (1995) provided the first assessment of the thermodynamic parameters involved in reaction (5). This experimental calibration conducted at 3-3.5 GPa (ca.100 km depth) has been widely used in numerous studies aimed at determining the oxygen fugacity of the deep mantle. All such studies have shown that mantle xenoliths becomes more reduced with depth of provenance (Ballhaus and Frost, 1994; Woodland and Koch, 2003; McCammmon and Kopylova, 2004; Rohrbach et al., 2007; Yaxley et al., 2012), with implications for metal and methane in the deep upper mantle (Ballhaus and Frost, 1994; Rohrbach et al., 2007; Rohrbach et al., 2014) (Fig. 4). This reducing trend has been most clearly observed on xenolith suites extracted from the thick lithospheric mantle underneath cratons, where the lithosphere is ancient and strongly depleted, even if secondary metasomatic processes have been locally reported (Creighton et al., 2009; O'Reilly and Griffin, 2012). The fact that Archean lithospheres are so thick, about $200 \mathrm{~km}$, allows deep xenoliths to be sampled by kimberlite magmas rising from the deeper asthenosphere. Elsewhere, xenoliths brought by lavas usually sample the mantle at maximum depths of $80 \mathrm{~km}$. One, seldom considered, possibility is that such reducing trend with increasing depth is specific to the Archean mantle. But the prevailing view is that several crystal chemistry controls involved in equilibrium (4) broadly buffer $\mathrm{fO}_{2}$ in the mantle as follows: garnet takes most of available ferric iron, whereas ferrous iron is preferentially taken by olivine and pyroxene; as garnet proportion increases with mantle depth it follows that oxygen becomes less and less available in the system (O’Neill et al., 1993; Ballhaus and Frost, 1994; Rohrbach et al., 2007). Initially, and until recently thought to lead to saturation in Fe-Ni-metal at depth due to an $\mathrm{fO}_{2}$ as low as FMQ-4 in the upper mantle (Ballhaus and Frost, 1994; Rohrbach and Schmidt, 2011), the magnitude of this effect has recently been re- 
evaluated (Stagno et al., 2013). Equilibrium (4) has been rewritten by Stagno et al (2013) following Luth et al (1990) as:

$$
\begin{aligned}
& 2 \mathrm{Ca}_{3} \mathrm{Fe}_{2} \mathrm{Si}_{3} \mathrm{O}_{12}+2 \mathrm{Mg}_{3} \mathrm{Al}_{2} \mathrm{Si}_{3} \mathrm{O}_{12}+4 \mathrm{FeSiO}_{3}=2 \mathrm{Ca}_{3} \mathrm{Al}_{2} \mathrm{Si}_{3} \mathrm{O}_{12}+4 \mathrm{Fe}_{2} \mathrm{SiO}_{4}+6 \mathrm{MgSiO}_{3}+\mathrm{O}_{2} \\
& \text { garnet }+ \text { garnet }+ \text { orthopyroxene }=\text { garnet }+ \text { olivine + orthopyroxene }
\end{aligned}
$$

Recalibration of equilibrium (7a) by Stagno et al. (2013) implies that oxygen fugacity around FMQ-3 can be reached at depths of 150-200 km (Fig. 4). The new oxybarometer calibrated by Stagno et al (2013) represents a considerable leap forward, although the thermodynamic data still suffer from significant uncertainties that translate into $\mathrm{fO}_{2}$ uncertainties of $\pm 1 \log$-unit $(1 \sigma)$. Note, however, that the garnet-olivine-pyroxene equilibrium of Stagno et al. (2013) tends to overestimate $\mathrm{fO}_{2}$ at low pressure and underestimate it at high pressure (see Fig.1B of Stagno et al., 2013). Further experimental work is clearly needed to properly settle this important issue. Addressing this point may well challenge the widely accepted concept of redox melting (Frost and McCammon, 2008; Rohrbach and Schmidt, 2011; Stagno et al., 2013), in particular if we consider that small changes in the inferred oxygen content of the asthenosphere (see 3.3.) implies important deepening of the redox melting region.

Overall and in spite of uncertainties in the thermodynamic calibrations, there is a general consensus that oxygen fugacity decreases with mantle depth due to the combined effects of garnet preferential uptake of ferric iron and its increasing modal proportions. In figure 4, oxygen fugacity is plotted against depth (after Stagno et al., 2013) showing that the redox state of the source regions of MORB and IOB, is in the range FMQ-1 \pm 1 . This broadly explains why melts produced in upwelling mantle regions have an oxygen fugacity near FMQ, though one still has to explain how MORB $\mathrm{fO}_{2}$ can increase by 1 order of magnitude from their source regions to the surface. Minor redox heterogeneities due to local variable 
enrichments in oxygen (including metasomatism) cannot be excluded, but such changes have been suggested to be largely buffered by the carbon speciation in the mantle source (Stagno et al., 2013). The $\mathrm{fO}_{2}$ dependency of carbon speciation (coexistence of diamond and melt with a $\mathrm{CO}_{2}$ mole fraction of ca. 0.2, after Stagno and Frost (2010)) along a mantle adiabatic curve is shown in Fig. 4. This curve shows that the diamond to carbonate conversion is very close to the $\mathrm{fO}_{2}$ of MORB and OIB source regions (both are in fact indistinguishable if we apply the $\mathrm{fO}_{2}$ uncertainties of $\approx \pm 1$ log-unit). At deeper levels, diamond will dominate which implies that during decompression, a redox melting event must occur producing carbonate-rich melts from diamonds. This reaction takes the oxygen made available by the garnet during decompression so that the net reaction can be written as follows:

$$
\mathrm{C}+2 \mathrm{Fe}_{3} \mathrm{Fe}_{2}{ }^{3+} \mathrm{Si}_{3} \mathrm{O}_{12} \quad \leftrightarrow \quad 4 \mathrm{Fe}_{2} \mathrm{SiO}_{4} \quad+2 \mathrm{FeSiO}_{3}+\mathrm{CO}_{2}
$$

This equilibrium is shifted to the right hand side as pressure decreases, resulting in a decrease in $\mathrm{Fe}^{3+} / \mathrm{Fe}_{\text {tot }}$ at the onset of (redox) melting. Rohrbach and Schmidt (2011) and Stagno et al. (2013) experimentally defined this redox melting to occur between 120 and 250 $\mathrm{km}$, depending on the ferric iron content of the system. More recently, to explain small changes documented in MORB Fe ${ }^{3+} / \mathrm{Fe}_{\text {tot }}(0.18-0.16)$, which correspond to 0.5 log-unit in $\mathrm{fO}_{2}$, Cottrell and Kelley (2013) have proposed that the less oxidized basalts are those richer in $\mathrm{CO}_{2}$. These effects remain small probably because the enriched mantle contains more $\mathrm{C}$ (Marty, 2012), but probably also more $\mathrm{Fe}^{3+}$, which overall results in a moderate impact on basalt $\mathrm{fO}_{2}$.

Altogether, we conclude that pressure is expected to drive redox equilibria toward more reducing conditions in the source region of mantle up-welling zones. Chemical enrichments may trigger heterogeneities but these effects may well compensate each other, and remain beyond reach of the precision afforded by currently available oxybarometer tools. 


\subsection{What is the redox state of the asthenosphere? A clue from low degree}

melts.

The redox profile through the upper mantle shown in Fig. 4 relies heavily on the ferric iron content measured in xenoliths from the lithosphere, simply because there are no rock samples from the asthenosphere that have been brought to the surface. Since the lithosphere has suffered from high degree of melting and melt extraction, the question of whether the trends of Fig 4 are representative of the asthenospheric mantle arises (see also Green et al. (1987) and Ballhaus and Frost (1994) for a discussion on the $\mathrm{fO}_{2}$ controls in the lithosphere vs. asthenosphere and the link with the redox state of $\mathrm{C}-\mathrm{O}-\mathrm{H}$ species in the source regions of basalts). Even if, for modern times, such a limitation is generally kept in mind by most authors (O’Neill et al., 1993; Canil et al., 1994; Canil and O'Neill, 1996), the need for a cautionary approach when studying the depleted Archaean lithosphere is obviously even stronger.

It is reasonably well established that during partial melting, ferric iron largely partitions in the melt, whereas ferrous iron tends to remain in the solid (Canil and O'Neill, 1996; Mallmann and O'Neill, 2009) though geochemical investigations do not always recognize this effect when plotting the oxidation state of MORBs normalized to a $\mathrm{MgO}$ content of $8 \mathrm{wt} \%$ (Bezos and Humler, 2005). Mantle partial melting is therefore unavoidably expected to deplete the residual solid in ferric iron resulting in a progressive decrease in $\mathrm{fO}_{2}$ (during the equilibrium melt formation and after melt removal). Both the extracted melt and the residual source are expected to be impacted by such reduction. As carbon behaves similarly to iron, in that only its oxidized form is soluble in the melt (e.g., Pawley et al., 1992), we expect that the oxygen fugacity of a primary melt, which, at equilibrium, is identical to that of its residue, does not reflect that of the subsolidus mantle. As the subsolidus mantle is the asthenosphere and the residual mantle is, to some extent, the lithosphere, it follows that the asthenospheric 
mantle must be, on average, more oxidized than both basalts and the lithosphere. A conceptual drawing (Fig. 5) illustrates the redox changes of the melt and of the solid residue during mantle partial melting. By definition, melt and residue are opposed in terms of enrichment/depletion in incompatible elements, but as melting is postulated to occur at equilibrium, their $\mathrm{fO}_{2}$ are identical. From Fig. 5, one expects that magmas produced by small degree of mantle melting would be the closest to that of the subsolidus mantle. Minettes, which are potassium rich melts produced by small degree of mantle melting, have long been identified as the most oxidized igneous rocks produced by mantle melting (Carmichael, 1991). Basanites, which are low silica, volatile-rich and alkali-rich melts, also typically produced at small degree of mantle melting (ca. $1 \%$ or less), have been shown to have very high oxidation states (Carmichael and Ghiorso, 1986), some of them being even saturated in sulphate minerals, which implies $\mathrm{fO}_{2}>\mathrm{FMQ}+2$ (Jugo et al. 2009; Jugo et al., 2010). Sulfate dissolved in low degree mantle melts, alkaline picrites and meimechites, is also suggested by Mungall et al (2006), based on $\mathrm{V}$ partitioning between melt and olivine, implying oxygen fugacity at ca. FMQ+2.5, and high chalcophile element concentrations suggesting the nearexhaustion of sulfide in the source mantle region. In a recent thorough survey, Moussallam et al. (2014) examined the redox state of the most primary melt inclusions found at Mt Erebus, an active volcano in a rifted setting. These inclusions, entrapped at the base of the Moho, are composed of basanite melts, with $\mathrm{Fe}^{3+} / \mathrm{Fe}_{\text {tot }}$ up to 0.36 (twice that of MORBs) with measurable amounts of dissolved $S^{6+}$ (Moussallam et al., 2014). Such alkaline melts may indicate the melting of veins with a particular chemistry in a layered, heterogeneous mantle (Pilet et al., 2008), in which case they would offer little insight on the oxidation state of the average mantle. If, in contrast, they are representative of small degree of melting of the $\mathrm{CO}_{2-}$ bearing mantle (Dasgupta and Hirschmann, 2010), this strongly suggests that the $\mathrm{fO}_{2}$ conditions prevailing during incipient mantle melting are close to FMQ+2, which is much 
higher than the redox conditions recorded by basalts and lithospheric residues. In summary, not enough attention has been paid to the $\mathrm{fO}_{2}$ of these small degree melts because they are usually considered as exotic, but they may tell us that the asthenosphere is critically more oxidized than a mere extrapolation from lithospheric suites would indicate.

\subsection{Subduction-related magmas: petrological vs. geochemical views on their} source region

The $\mathrm{fO}_{2}$ of subduction-related rocks ranges from 0.5 below to 4 log-units above the FMQ buffer (Carmichael 1991; Behrens and Gaillard 2006; Pichavant and McDonald 2007; Rowe et al., 2009; Kelley and Cottrell, 2009; Evans et al., 2012). High $\mathrm{fO}_{2}$ impacts on magmatic differentiation and Fe-depletion (e.g., Martel et al. 1999; Behrens and Gaillard 2006; Pichavant and Mcdonald 2007; Jenner et al., 2010; see section 3.5.) but also on the ability of mantle melts to extract and convey various metallic elements and sulfur to the crust (e.g., Jugo 2009; Jenner et al., 2010; Botcharnikov et al., 2010; Jego and Pichavant, 2012; Prouteau and Scaillet, 2013; Jego and Dasgupta, 2013), which can subsequently lead to the formation of shallow ore deposits (Mungall et al. 2002; Jenner et al., 2010). Although most arc-basalts have $\mathrm{fO}_{2}$ around FMQ+1.5 \pm 1 (Carmichael 1991; Behrens and Gaillard 2006; Rowe et al., 2009; Kelley and Cottrell, 2009; Kelley and Cottrell, 2012), it is worth noting that significantly higher values have been found for primitive arc magmas, especially at the Antilles Islands (see Stamper et al., 2014): for instance, at Grenada, Parkinson et al. (2003) reported mantle basalts with $\mathrm{fO}_{2}$ at FMQ +2.5 (see also Stamper et al., 2014) and at St Vincent, Pichavant and MacDonald (2007) identified primitive basalts with $\mathrm{fO}_{2}$ up to FMQ+3.

Although well documented, and despite decades of efforts, the reason for oxidizing conditions in arc magmas is not clearly understood. Rowe et al (2009), Kelley and Cottrell 
(2009) and Zimmer et al. (2010) highlighted a correlation between the magmatic $\mathrm{fO}_{2}$ and the slab-derived fluid components. In particular, Kelley and Cottrell (2009) show a positive correlation between $\mathrm{H}_{2} \mathrm{O}$ content in the melt and $\mathrm{Fe}^{3+} / \mathrm{Fe}_{\text {tot }}$, a correlation which, as they note, does not imply that water is the oxidative component. Such a $\mathrm{H}_{2} \mathrm{O}-\mathrm{Fe}^{3+} / \mathrm{Fe}_{\text {tot }}$ correlation can nevertheless reflect the following equilibrium, long used in hydrothermal experiments (Scaillet et al., 1992; Gaillard et al. 2002; Botcharnikov et al. 2005):

$$
\mathrm{H}_{2} \mathrm{O} \Leftrightarrow \mathrm{H}_{2}+1 / 2 \mathrm{O}_{2} \quad f_{\mathrm{O}_{2}}=\left(\frac{f_{\mathrm{H}_{2} \mathrm{O}}}{f_{\mathrm{H}_{2}} \times K^{P, T}}\right)^{2}
$$

$\mathrm{K}^{\mathrm{P}, \mathrm{T}}$ being the thermodynamic constant of eq. (9). The $\mathrm{f}_{\mathrm{O} 2}$ of a water-bearing fluid increases as water fugacity increases ( $\mathrm{f}_{\mathrm{H} 2 \mathrm{O}}$, increasing water content) assuming that hydrogen fugacity $\left(f_{\mathrm{H} 2}\right)$ remains fixed. In nature, there is no a priori reason to have constant $\mathrm{f}_{\mathrm{H} 2}$, which must be relaxed to define the effect of $\mathrm{H}_{2} \mathrm{O}$ addition on the $\mathrm{f}_{\mathrm{O} 2}$ of basalts. Figure 6 quantifies such an "intrinsic" effect of water on the $\mathrm{f}_{\mathrm{O} 2}$ of basalts. We consider a moderately reduced fluid saturated water-poor basalt $\left(0.1 \mathrm{wt} \% \mathrm{H}_{2} \mathrm{O}, 1250 \mathrm{ppm} \mathrm{S}, 1250^{\circ} \mathrm{C}, 0.6 \mathrm{GPa}\right.$, FMQ-0.2; the amount of $\mathrm{CO}_{2}$, ca $4000 \mathrm{ppm}$, is adjusted to trigger fluid saturation at the pressure of $0.6 \mathrm{GPa}$ ) and we add $\mathrm{H}_{2} \mathrm{O}$ to this basalt-fluid system. The choice of $0.6 \mathrm{GPa}$ is motivated by the pressure range of calibration of the solubility laws we combine here and the fact that we impose fluid saturation. Similar calculations at higher pressure (1.5 GPa) would certainly differ in the details, but the conclusions we expose below would remain unchanged. We compute how $\mathrm{H}_{2} \mathrm{O}$ redistributes between melt and fluid and decompose as $\mathrm{H}_{2}$ and O-species bound to other cations; in the meantime $\mathrm{CO}_{2}$ is diluted as $\mathrm{H}_{2} \mathrm{O}$ fugacity increases; all this causes the shift of equilibrium 9 to the right. Homogeneous and heterogeneous equilibrium are solved together (see Gaillard et al., 2011) and this allows the strict effect of $\mathrm{H}_{2} \mathrm{O}$ addition on the $\mathrm{fO}_{2}$ of basalt to be resolved. We see in Fig. 6 the moderate oxidizing effect of water that is evocated by Hirschmann (2009): $10 \mathrm{wt} \%$ of added water increases the $\mathrm{fO}_{2}$ by 0.5 log-unit 
that is, an increase from FMQ to NNO. Part of the reason for this is that adding $\mathrm{H}_{2} \mathrm{O}$ to the system displaces eq. (9) to right, producing $\mathrm{H}_{2}$ and moderating the oxidizing effect of water.

Brandon and Draper (1996) have suggested the H-loss $\left(\mathrm{H}_{2}\right.$-loss being more correct) mechanism during metasomatism to oxidize the mantle wedge. The dissociation of $\mathrm{H}_{2} \mathrm{O}$ (eq. 9) produces $\mathrm{H}_{2}$ and $\mathrm{O}_{2}$. Assuming that $\mathrm{H}_{2}$ can be lost via selective diffusion, Brandon and Draper (1996) suggested that the remaining metasomatized mantle becomes enriched in $\mathrm{O}_{2}$, providing an explanation for the high oxidation state of arc-basalts. This model, however, has been criticized by Frost and Ballhaus (1998) who argued that the hydrogen loss process cannot be an effective oxidative process because of feedback effects in equilibrium (9) which were not considered by Brandon and Draper (1996). Indeed, $\mathrm{H}_{2}$-loss can displace eq. (9) to the right hand side, but the oxidative effect becomes vanishingly small as the fraction of $\mathrm{H}_{2}$ tends to zero. The hydrogen loss model is nevertheless not completely buried as discussed later (Holloway, 2004).

Although the conventional wisdom attributes the oxidizing conditions in arc-basalts to the income of volatile-rich fluids (from the downgoing dehydrating slab) into the mantle wedge (Kelley and Cottrell 2009), worldwide geochemical surveys have so far failed to give a firm support to such a contention. In particular, Mallmann and O’Neill (2009), Lee et al. (2010) and Lee et al. (2012), using various redox sensitive ratios ( $\mathrm{Zn} / \mathrm{Fe}, \mathrm{V} / \mathrm{Sc}$, and $\mathrm{Cu}$ systematics in basalts), have concluded that primary arc-basalts are not significantly more oxidized than other primary MOR-basalts. The emerging conclusion from such global approaches carried out over different geodynamic settings is that oxidation of basalts must occur during their shallower maturation, when the $\mathrm{MgO}$ content of the residual liquid is lower than $8 \mathrm{wt} \%$. The processes conducive to such oxidation remain, however, unidentified and we question below several suggested oxidative paths. 
In contrast to global approaches, detailed petrological surveys (Parkinson et al. 2003; Pichavant and McDonald 2007) have shown that primary arc basalts, hence their source, are significantly oxidized (FMQ+1/+2), and suggest that upon basalt differentiation, oxygen fugacity may further increase (to FMQ+3). The mantle xenoliths carried by these basalts are similarly oxidized (Evans et al., 2012). Consistently with such petrological surveys, geochemical observations tackling the nature of fluids in the mantle wedge also call for highly oxidizing conditions at early stages: high $\mathrm{U} / \mathrm{Th}$ ratio and occurrence of $\mathrm{As}^{5+}$ clearly point toward oxidized water-rich fluids (Hattori et al. 2005; Bali et al. 2011).

Summing up, it is generally accepted that arc-magmas are more oxidized than MORBs and OIB. It is however still debated whether this oxidized nature is inherited from peculiar melting conditions in the wedge, which could be related to the fluxing of volatile-rich fluids from the downgoing slab, or acquired during the ascent of magma to the surface, which must be related to differentiation and/or degassing (Lee et al., 2010, 2012). An alternative could be that the oxidative component is added after the decompressing melting stage; indeed, decompression melting is expected to occur in the mantle wedge (Lee et al., 2010), and waterrich oxidized fluids could be later "assimilated", offering a reconciliation of all measurements. A numerical test of this scenario is shown in fig.6 where a hydrous fluid mixture, variably enriched in $\mathrm{SO}_{2}$ and $\mathrm{SO}_{3}$ (see Kelley and Cottrell, 2009; Alt et al., 2011; Debret et al., 2014), is assimilated by a moderately reduced and dry basalt. We can see that a hydrous fluid charged in $\mathrm{SO}_{2}$ can significantly increase the basalts $\mathrm{fO}_{2}$, but this effect remains limited and hampered by the melt speciation $S^{6+} / S^{2-}$ shift at FMQ+1, which acts as a redox barrier that cannot be overcome by adding $\mathrm{SO}_{2}$. In contrast, addition of hydrous fluids being rich in $\mathrm{SO}_{3}$ can produce basalt with $\mathrm{fO}_{2}$ of the order of $\mathrm{FMQ}+3$, that is, the most oxidized primary arc-basalts so far identified. The flow through the mantle wedge and the assimilation of sulfate-rich hydrous fluids could therefore generate hydrated and oxidized basalts although 
our simulations are done at moderate pressure and several details in the chemical trends of figure 6 could be modified by applying a higher pressure (1.5 GPa). We underline here that the fluid can be either a silicate (Prouteau and Scaillet, 2012; Jego and Dasgupta, 2013) or a hydrous component (Alt et al., 2011).

The petrologic studies agree in seeing primary basaltic melts being oxidized from the beginning, but those studies remain local, and it cannot be ruled out that the Antilles example represents an exception (slow spreading ridge, intensively serpentinized...). For other subduction zones, we do not have robust $\mathrm{fO}_{2}$ or ferric-ferrous ratio measurements on primary magmas, preventing the direct assessment of their source redox state, which needs therefore to be evaluated from magmatic suites on more fractionated melts (Kelley and Cottrell, 2012). The strengths of geochemical approaches based on $\mathrm{V} / \mathrm{Sc}, \mathrm{Zn} / \mathrm{Fe}$ and $\mathrm{Cu}$ systematics is that, besides being global, they can, in principle, filter out degassing or differentiation, which are likely to modify the redox signature of the primary melts. Such purely geochemical approaches give results that, however, can be model dependent and therefore difficult to globalize. For instance, Lee et al (2012) used the copper content of primary arc basalts to determine the $\mathrm{fO}_{2}$ during melting in the mantle wedge at saturation with molten FeS. Model assumptions include a given bulk sulfur content and a given degree of melting. Because there exists a variety of combinations, the sole $\mathrm{Cu}$ content in basalts appears sensitive to many parameters in addition to $\mathrm{fO}_{2}$. In particular, the assumption of sulfur content in mantle wedge being similar to the average mantle (ca $200 \mathrm{ppm}$ ) is highly debatable in view of the evidence pointing to the massive recyling of sulfur in subduction zones (Jambon, 1994; Metrich et al., 1999, 2009; Alt et al., 2011; Prouteau and Scaillet, 2012, Jégo and Dasgupta, 2013). Similarly, the $\mathrm{Zn} / \mathrm{Fe}$ systematics used in Lee et al (2010) to track back the redox state of primary arc-melts essentially record the onset of magnetite precipitation, also known as the magnetite crisis (Jenner et al., 2010). The lack of $\mathrm{Zn} / \mathrm{Fe}$ fractionation in primary arc-basalts is 
interpreted by Lee et al (2010) as the proof that these melts are not oxidized from the beginning. Yet, phase-equilibrium constraints show that oxidized primary basalt do not crystallize magnetite but Cr-spinel instead (Pichavant and McDonald, 2007) so the absence of $\mathrm{Zn} / \mathrm{Fe}$ fractionation is expected for both oxidized and reduced primary basalts. In fact, the chemistry of chrome spinel indicates oxidative conditions from the beginning for arc-basalts (Pichavant and McDonald, 2007). Like for Cu systematics, the absence of $\mathrm{Zn} / \mathrm{Fe}$ fractionation cannot unambiguously be taken as a proof that primary arc-basalts are not oxidized. Hence, despite various attempts (Parkinson et al., 2003; Rowe et al., 2009; Kelley and Cottrell, 2009; Kelley and Cottrell, 2012; Evans et al., 2012), we still lack the firm evidence that primary arcbasalts can be oxidized right from the beginning; there is a variety of geochemical and petrological observations that contradicts each other's, with some reflecting global trends and others being representative of regional controls.

\subsection{Subduction-related magmas: Fractionation, degassing and $\mathrm{fO}_{2}$}

Oxygen fugacity has long been described as a critical parameter in crystal-liquid fractionation (differentiation) and gas-liquid equilibria (degassing). In turn, crystallization and degassing can affect magmatic $\mathrm{fO}_{2}$ and could account for the oxidized nature of many arc basalts. Both processes are summarized below. In addition, the volume changes of the reaction of iron speciation in silicate melt $\left(\mathrm{FeO}_{1.5}=\mathrm{FeO}+1 / 4 \mathrm{O}_{2}\right)$ has long been shown to induce an decrease in oxygen fugacity during magma decompression (Kress and Carmichael, 1991). This effect is, however, relatively small.

Magma fractionation at oxidizing conditions

Redox controls on crystallization and magmatic differentiation in arcs has long been viewed as specific, being responsible for the generation of the continental crust (e.g., Tatsumi 
and Suzuki, 2009). Arc basalts evolve along fractionation trends leading to high $\mathrm{SiO}_{2}$ and low $\mathrm{FeO}_{\mathrm{t}} / \mathrm{MgO}$ in derivative products. Recent interpretations have emphasized the role of $\mathrm{H}_{2} \mathrm{O}$ in promoting such a calc-alkaline evolution (Zimmer et al. 2010), despite $\mathrm{H}_{2} \mathrm{O}$ concentrations going along with a marked (up to 2-3 log units) increase in $\mathrm{fO}_{2}$. Experiments under controlled hydrous and redox conditions have successfully simulated arc magma evolutionary trends (Sisson and Grove 1993; Pichavant et al. 2002; Pichavant and Macdonald 2007). Residual melts covering the whole range of natural fractionation trends encountered in arc settings were reproduced by varying $\mathrm{fO}_{2}$ between $\mathrm{FMQ}+0.5$ and FMQ+4 (Pichavant et al. 2002). These experiments reveal that the tholeiitic vs. calc-alkaline dividing line in the $\mathrm{FeO}_{\mathrm{t}} / \mathrm{MgO}$ vs. $\mathrm{SiO}_{2}$ plot (Miyashiro 1974) is in fact an oxyisobar, being coincident with a fractionation trend buffered at FMQ+1.5. The proportion of crystallizing spinel exerts an important influence on the $\mathrm{FeO}_{\mathrm{t}} / \mathrm{MgO}$ of the residual melt. Early spinel crystallization has been ascribed to the influence of hydrous conditions (Sisson and Grove 1993; Zimmer et al. 2010). However, other factors such as high $\mathrm{fO}_{2}$ (and the $\mathrm{Cr}$ concentration) are more effective than $\mathrm{H}_{2} \mathrm{O}$ in stabilizing spinel near the liquidus of basaltic melts (Pichavant and Macdonald 2007). The picture that emerges from these experiments is that an oxidizing fO2 exerts the dominant control on arc magma differentiation even if the factors that control the redox evolution are still to be completely understood.

Kelley and Cottrell (2012) have investigated the role of magmatic differentiation on the oxidation state of Fe in arc-basalts. Crystal-liquid equilibria have been proposed to fractionate ferric from ferrous iron (Carmichael and Ghiorso, 1986), which must result in changes in the $\mathrm{Fe}^{3+} / \mathrm{Fe}_{\text {tot }}$ of the residual melt and then translates into a change in $\mathrm{fO}_{2}$. Tracking $\mathrm{Fe}$ oxidation state in a suite of mafic melts from the Mariana Island with variable degree of differentiation $(\mathrm{MgO}=8$ to $3 \mathrm{wt} \%)$, Kelley and Cottrell (2012) and Crabtree and Lange (2012) have inferred a weak impact of olivine, clinopyroxene and magnetite fractionation on the oxidation state of 
Fe in the differentiated melts. Crystallisation is therefore not suggested to be the driving force capable of oxidizing arc-basalts during their ascent from the mantle wedge.

Closed vs. open system degasing

The hydrogen loss model (Sato, 1978; Candela, 1986; Holloway, 2004) stipulates that self-oxidation of hydrous melts can occur via $\mathrm{H}_{2}$ loss toward the surroundings (infiltration of fluid into wall-rock or degassing via differential bubble escape). This idea is rooted on the high mobility and low solubility of $\mathrm{H}_{2}$ in silicate melts (Sato, 1978; Gaillard et al., 2002; Gaillard et al., 2003a,b). But loss by diffusion has been modelled in Gaillard et al (2002; 2003b) and shown to be unable to affect large volume of magmas. Even if $\mathrm{H}_{2}$ diffuses fast, the diffusion of heat remains several orders of magnitude higher (Gaillard et al., 2003b) implying that magma would cool down far more rapidly than it would get oxidized by this mechanism. The alternative H-loss process involves the loss of the fluid phase (Candela, 1986). Arcmagmas being rich in volatiles, they usually reach saturation in gas forming species $\left(\mathrm{H}_{2} \mathrm{O}\right.$, $\mathrm{CO}_{2}, \mathrm{~S} \ldots$ ) at crustal depth (tens of kilometres) causing the nucleation of bubbles. Since reduced volatile species $\left(\mathrm{H}_{2}, \mathrm{CO}, \mathrm{CH}_{4}\right)$ have solubilities in silicate melts several order of magnitude lower than their oxidized counterparts $\left(\mathrm{H}_{2} \mathrm{O}, \mathrm{CO}_{2}\right)$, they concentrate in the exsolved vapour phase. Since bubble segregation in mafic magmatic bodies is fast and efficient (e.g., Menand and Phillips, 2007), it can be anticipated that degassing and loss of the fluid phase triggers a preferential loss of reduced species, which may impact on the redox state of the residual magmatic system. In figure 7, we model open vs. closed system equilibrium degassing of a volatile-rich magma during its ascent through the crust $(30 \mathrm{~km}$ of ascent) (for methods see Gaillard et al., 2011; Iacono-Marziano et al., 2012b; IaconoMarziano et al., 2013; Gaillard and Scaillet, 2014). The closed system degassing paths indicate that the redox state of the melts that reach the surface represents well its source (ie. its pre-degassing redox state). Open degassing conditions systematically produce an oxidizing 
trend as the magma moves to the surface; this oxidizing shift is more important if predegassing conditions are more reduced. More reduced magmas saturate, at depth, with a fluid phase richer in reduced species $\left(\mathrm{H}_{2}, \mathrm{CO}, \mathrm{CH}_{4}\right)$, and the loss of these species enhances oxidation. A magma initially formed at FMQ-0.5 can gain one log-unit in $\mathrm{fO}_{2}$ by the mechanisms of fluid phase loss. In the examples shown, the oxidation step initiates at 1000 bar, which corresponds to the pressure of beginning of exsolution of hydrated species from mafic melts having $3 \mathrm{wt} \%$ water (Iacono-Marziano et al., 2013). Water-richer melts would deepen the exsolution stage and therefore further exacerbate the oxidation by fluid loss. We hence conclude that the oxidative potential of fluid loss from a moderately and water rich reduced melt is non-negligible. This process reconciles the fact that arc-basalts are not oxidized from their source, but become oxidized during their ascent through the crust because they are water-rich. But, as pointed out by Frost and Balhaus (1998), this process is selflimiting as the more oxidized is the magma, the less $\mathrm{H}_{2}$ and CO-rich are the fluids, and the less oxidizing is the effect of fluid loss. This is illustrated in Fig. 7, where it is apparent that the oxidation process by fluid loss becomes negligible for initial $\mathrm{fO}_{2}$ higher than $\mathrm{FMQ}+0.5$. Therefore, fluid loss can oxidize reduced and water-rich primary melt during their ascent through the crust, but the above modelling shows that such a mechanism cannot explain magmas with $\mathrm{fO}_{2}>\mathrm{FMQ}+1$, ie the range typical for arc-magmas.

The degassing itself, whether it occurs under close or open system conditions, has been suggested to change magmatic $\mathrm{fO}_{2}$ (Mathez, 1984; Carmichael and Ghiorso, 1986; Carmichael, 1991; Burgisser and Scaillet, 2007; Gaillard et al., 2011; Kelley and Cottrell, 2012; Metrich et al., 2009; Moussallam et al., 2014). Much attention has been paid to the outgassing of sulfur (Carmichael, 1991; Gaillard et al., 2011; Kelley and Cottrell, 2012; Metrich et al., 2009; Moussallam et al., 2014), being present in basaltic melts as $S^{2-}$ and $S^{6+}$ (Jugo, 2009; Jugo et al., 2010), and in the fluid phase as $\mathrm{H}_{2} \mathrm{~S} / \mathrm{S}_{2} / \mathrm{SO}_{2}$ (oxidation state -II, 0 , 
+IV; Gaillard and Scaillet, 2009). Fig. 8 shows the $\mathrm{fO}_{2}$ changes in response to sulfur outgassing from mafic melts having different initial $\mathrm{fO}_{2}$ and water contents. The choice of such initial conditions reflects the expected spectrum for the primary melts from MORB, OIB to arc-basalts, that is, in this order, increasingly hydrated and oxidized. The pattern obtained in Fig. 8 is quite simple. The degassing of moderately reduced primary melts, such as MORB and OIB, induces a reduction of the melt as the sulfur degassed consumes oxygen via the following reaction:

$$
\mathrm{FeS}^{\text {basalt }}+3 / 2 \mathrm{O}_{2}=>\mathrm{FeO}^{\text {basalt }}+\mathrm{SO}_{2}^{\text {fluid }}
$$

The degassing of oxidized primary melts produces a moderately oxidizing effect as it releases oxygen via:

$$
\mathrm{SO}_{3}{ }^{\text {basalt }}=>\mathrm{SO}_{2}{ }^{\text {fluid }}+1 / 2 \mathrm{O}_{2}
$$

The inversion of the degassing effect on magmatic $\mathrm{fO}_{2}$ indicates a global trend converging toward either sides of the sulphide/sulphate speciation curve, which occurs in the $\mathrm{fO}_{2}$ range $\mathrm{FMQ}+0.5-\mathrm{FMQ}+1.5$. It is deceptively simple to conceive that all primary melts would be formed in such a narrow range of $\mathrm{fO}_{2}$. One important implication of the above is that it is almost impossible to distinguish the oxidation state of primary melts produced in upwelling regions (MORB, OIB) from those produced in the fluxed mantle wedge (arcs), once they have migrated to shallow crust levels or have been emitted subaerially. This also implies that the buffers controlling the oxidation of the vast majority of mantle melts is the sulfide/sulfate speciation curve in basalts, and that this redox barrier can only be overcome by the fluxing processes operating in the mantle wedge.

\subsection{Analysis of the redox transfers at subduction zones}


At subduction zones, a variety of chemical species, which are marginally present in the Earth's mantle, are buried with the plunging lithosphere. These chemical species are volatilerich and oxidized as a result of seawater-rock exchanges at the ocean floor. Such a chemical status contrasts with that of the canonical mantle, being reduced and volatile-poor. In brief, prior to entering a subduction zone, the oceanic lithosphere undergoes an important enrichment in oxygen-hydrogen-carbon and sulfur (Fig. 9). Oxygen enrichment is coupled with the hydration of basalts and the serpentinization of peridotite (Lecuyer and Ricard, 1999; Honnorez, 2003; Evans, 2008), both processes producing rocks enriched in ferric iron. Carbonatation of eclogites and peridotites can occur and convey carbonates into the mantle; Sulfidation at various lithospheric depths is also recognized to occur, and except at the seafloor surface, deposits of sulfate minerals seem unimportant (Padron-Navarta et al., 2011; Alt et al., 2012). The fate of these species in subduction zones is documented by petrological and geochemical studies, although the details of the reaction paths involved are unkown (Wallace, 2005; Evans, 2012). It is generally accepted that carbonates by-pass the region of dehydration/melting beneath arc-volcanoes (Connolly, 2005; Malaspina et al., 2008; Poli et al., 2009) and are buried in the deep mantle (Hammouda, 2003; Dasgupta and Hirschmann, 2010,). A few arc-volcanoes produce elevated amount of $\mathrm{CO}_{2}$, but it is unclear whether this $\mathrm{CO}_{2}$ has really been processed through the mantle wedge or is simply assimilated during magma transport and storage in the upper crust (Iacono-Marziano et al., 2009). Subduction of carbonates has implications for redox processes in the deep mantle as carbonates decompose into diamonds and liberate oxygen (Rohrbach and Schmidt, 2011), hence increasing the amount of oxygen in the mantle. The magnitude of this increase depends on the amount of carbonate minerals transferred into the mantle by subduction and whether this modern fate of subducted carbonates was already operating in the ancient Earth or not (Dasgupta and 
Hirschmann, 2010). No consensus has been reached on any of these points, except on the fact that carbonate subduction results in an oxygen gain for the deep mantle (Evans, 2012).

Rocks surviving serpentine dehydration show a $\mathrm{Fe}^{3+} /$ Fetot ratio of about 0.3 (PadronNavarta et al., 2011), which is much more elevated than the mantle value of $0.02-0.05$ (O’Neill et al. 1993; Stagno et al., 2013; Cottrell and Kelley, 2011). Based on modern subduction rates (see also $\mathrm{Li}$ and Lee, 2006), assuming subduction of serpentinite having $\mathrm{Fe}^{3+} /$ Fetot ratio of 0.35 (Padron-Navarta et al., 2011) and considering an average degree of serpentinization of the oceanic lithosphere as given in Schmidt and Poli (1998) and Li and Lee (2006), it can be calculated that ca. $0.5-2 \times 10^{15} \mathrm{~g} / \mathrm{year}$ of $\mathrm{Fe}_{2} \mathrm{O}_{3}$ is buried in the mantle by serpentinite subduction. Dehydrated eclogites also show high $\mathrm{Fe}^{3+} / \mathrm{Fe}_{\text {tot }}$, resulting in flux of $\mathrm{Fe}_{2} \mathrm{O}_{3}$ of $6-11 \times 10^{14} \mathrm{~g} /$ year (Lecuyer and Ricard, 1999). The deep burial of these rocks must increase the mantle $\mathrm{fO}_{2}$ by increasing its oxygen / cation ratio (see Evans (2012) similar calculations presented in terms of redox budget). If $2 \times 10^{15} \mathrm{~g} /$ year gr of $\mathrm{Fe}_{2} \mathrm{O}_{3}$ is sent into the deep mantle (without reacting with reduced carbon), subduction of such oxidized rocks over the last $2 \mathrm{Ga}$ must then have increased the $\mathrm{Fe}_{2} \mathrm{O}_{3}$ of the upper mantle by $0.20-0.35 \mathrm{wt} \%$, implying that the amount of $\mathrm{Fe}_{2} \mathrm{O}_{3}$ in the upper mantle must have almost doubled since subduction has initiated; in response, mantle $\mathrm{fO}_{2}$ should have significantly increased (ca from FMQ-3 to FMQ). This estimate takes into account the fact that a part of the ferric iron buried in subduction zones is returned via arc-volcanoes (following Lecuyer and Ricard, 1999) but it does not consider the amount of ferric iron stored in the cold mantle wedge, which contains serpentine and chlorite minerals (Guillot et al., 2001), both being known to store large amount of ferric iron (Evans, 2008; Padron-Navarta et al., 2011).

Subducted sulfides are affected by dehydration/melting processes in the plunging lithosphere (Alt et al., 2012; Prouteau et al., 2012; Jego and Dasgupta, 2013). Upon 
dehydration/melting, sulfides undergo an oxidation into $\mathrm{SO}_{2}$ or $\mathrm{SO}_{3}$ (Alt et al., 2012; Debret et al., 2014). Oxidation of sulfur is accompanied by a modest reduction of ferric iron (50 to $30 \% \mathrm{Fe}^{3+} / \mathrm{Fe}_{\text {tot }}$ ) as reported in chemical analyses on exhumed serpentinites (Padron-Navarta et al., 2011). Sulfur is subsequently transferred to arc-volcanoes where it is degassed as $\mathrm{SO}_{2}$. The subduction-cycling-degassing of sulfur through the subduction-arc cycle results in an oxygen loss for the deep mantle, but it is a moderate and relative loss as, in fact, the overall result of sulfur subduction implies less ferric iron enrichment for the deep mantle rather than oxygen loss.

In summary, this simple analysis of fluxes at modern subduction globally indicates that subduction is an oxygen sink for the atmosphere and an oxygen source for the deep mantle (see Evans (2012) for more details). Any link between atmospheric oxygenation at $2.4 \mathrm{Ga}$ and the onset of modern subduction seems therefore unlikely, or other reaction paths must be sought for. Alternatively, the effect can be indirect, i.e. subduction triggers an oxygen enrichment of the deep mantle, which impacts the $\mathrm{fO}_{2}$ evolution of mantle-derived basalts on the long term something which is, however, not sampled by paleo-oxybarometric studies (Canil, 1997; Delano, 2001; Li and Lee, 2005).

\section{Archean temperature \& source regions of Komatiite and archaean basalts}

Although the mantle underneath ancient continents indicates oxygen fugacity down to FMQ-3 (Woodland et al., 2003; Yaxley et al., 2013; Stagno et al., 2013), geochemical investigations on the oldest possible magmatic rocks did not reveal any significant deviation from FMQ in mantle-derived magmas $\mathrm{fO}_{2}$ (Canil, 1997; Delano, 2001; Li and Lee, 2005). The processes able to buffer mantle oxygen fugacity remain unclear, although this review has tentatively brought some new statements. 
Of all the possible changes the Earth underwent during the Archean to early Proterozoic era, heat dissipation and progressive cooling of the mantle is the most largely recognized. This implies a decrease in melt production rate and melting degrees of the mantle with time (Herzberg et al., 2010; Keller and Schoene, 2012). An expected consequence of mantle cooling through the Archean era is that mantle melting must occur at shallower depth as illustrated in figure 4 (Sleep and Windley, 1982). Present-day MORBs result from mantle melting at depth of 40-60 km. Hotspot lavas, whether hot or wet, must be extracted from melting processes that initiate at slightly greater depth than MORB. Archean basalts must derive from melting that initiates at depths exceeding $150 \mathrm{~km}$ and komatiite lavas must result from mantle melting at 200-250 km depth. This is also consistent with phase equilibrium constraints that define melt-mantle equilibration for komatiites at 6-7 GPa (Walter, 1998). The consequence of deeper region of melting for a hotter mantle is that Archean lavas must have been born more reduced than present-day lavas. Actually, Berry et al. (2008) reported olivine hosted melt inclusions found in komatiites with $\mathrm{Fe}^{3+} / \mathrm{Fe}_{\text {tot }}$ of $0.1( \pm 0.02)$, which is lower than that in MORBs $\left(\mathrm{Fe}^{3+} / \mathrm{Fe}_{\text {tot }} \sim 0.16\right.$, see Cottrell and Kelley, 2013) and may indicate that hot archaean lavas are more reduced than present day ones. Figure 4 indeed indicates that komatiite parental magmas have been formed in region where the prevailing mineral assemblages must impose oxygen fugacity around FMQ-3. At such depth, ferric iron is compatible and tends to remain in the solid residue consistent with the observation that the deepest garnets underneath cratons preserve the highest $\mathrm{Fe}^{3+} / \mathrm{Fe}_{\text {tot }}$ ratios (Woodland et al., 2003). Deeper and more reduced Archean magmas however conflict with V/Sc and other proxies indicating the constancy of magma redox state. In this analyse, we ignore the possibility that the deep magmas formed deeper during the Archaean partly re-equilibrated during the ascent through the thick Archaean lithosphere, which may modify their $\mathrm{fO}_{2}$ and 
reset their V/Sc ratios. The mechanisms allowing such redox re-equilibration remain, however, to be identified.

\section{Perspectives: is there a buffer in the Earth's mantle?}

The redox state of basalts being broadly inherited from that of its mantle source has a prime role on the composition of volcanic gases. Any modification of this parameter is expected to severely impact on the surficial cycles of elements such as carbon, sulfur and oxygen. Although the redox state of the mantle must have changed since the core has segregated, available evidence suggests that such a change has occurred prior to $4 \mathrm{Ga}$, while the permanent oxygenation of the atmosphere is currently documented to have occurred more than 1.5 Ga years after. Both phenomena seem therefore to be largely, if not totally, unrelated.

It is unclear how $>2$ Ga years of subduction, melting, metasomatism and other longstanding processes can have triggered large geochemical heterogeneities (depletion and enrichment) and would in the meantime produce melts having the same redox potential within error. This is reinforced by quantitative analyses of the redox transfers at subduction (Lecuyer and Ricard, 1999; Foley, 2012; Evans 2012) indicating that oxygen rich rocks must be introduced in the deep mantle, inescapably triggering deep redox heterogeneities. The buffering capacity of the solid upper mantle, that is, the ability of mineralogical components in peridotites to absorb oxygen with a minimum of changes in $\mathrm{fO}_{2}$, is limited. The garnetorthopyroxene-olivine reaction involves only a limited amount of (ferric) iron in garnet (Woodland et al., 2003; McCammon and Kopylova, 2004; Rohrbach et al., 2007; Stagno et al., 2013) and the shift in oxidation state from ferrous to ferric iron is only +1 . So the silicate upper mantle does not seem able to absorb/desorb enough oxygen to maintain its $\mathrm{fO}_{2}$ constant 
during melting, metasomatism, or introduction of oxygen-enriched rocks by subduction processes.

Another buffer must prevail in the mantle in addition to iron. In the asthenosphere, carbon that can be either diamonds $\left(\mathrm{C}^{0}\right)$ or carbonates $\left(\mathrm{C}^{+\mathrm{IV}}\right)$, is an efficient redox buffer provided that its concentration is high enough (Canil et al., 1994). The carbon content of the Earth's mantle is however poorly known (Cartigny et al., 2008; Iacono-Marziano et al., 2009; Dasgupta and Hirschmann, 2010), the reason being that basalts degas their $\mathrm{CO}_{2}$ much before reaching the Earth's surface. Marty (2012) estimated that the depleted mantle contains a few tens of ppm wt. of carbon while the enriched mantle, so far unaffected by (melting and) degassing, may contain 500 ppm C. If such a reservoir remains hidden in the mantle it can indeed constitute an huge redox capacity, explaining the constancy in mantle $\mathrm{fO}_{2}$ through time and space. But the carbon - carbonate equilibrium would buffer a mantle $\mathrm{fO}_{2}$ at values actually lower than those recorded by basalts and rocks of the lithosphere (Rohrbach and Schmidt, 2011; Stagno et al., 2013). We have exposed several reasons of why the oxidation state of basalts may well be lower than that of it subsolidus source, that is, the asthenosphere. If true, the presence of sulfate in melts produced at the beginning of partial melting (Mungall et al., 2006; Moussallam et al., 2014) must be considered. The oxidative capacity of metasomatic events observed in a variety of settings (intraplate to subduction regions) may well be connected to sulfate-rich fluids, including in the mantle wedge.

\section{References.}

Alt J.C., Garrido C.J., Shanks III W.C., Turchyn A., Padrón-Navarta J.A., SánchezVizcaíno V.L., Gómez Pugnaire M.T., Marchesi C., 2012. Recycling of water, carbon, and 
sulfur during subduction of serpentinites: A stable isotope study of Cerro del Almirez, Spain, Earth and Planetary Science Letters 327, 50-60.

Bali E., Audétat A., Keppler H., 2011. The mobility of U and Th in subduction zone fluids: an indicator of oxygen fugacity and fluid salinity. Contribution to Mineralogy and Petrology 161, 597-613. DOI: 10.1007/s00410-010-0552-9.

Bali E., Audétat A., Keppler H., 2011. Water and hydrogen are immiscible in Earth's mantle. Nature 495, 220-222. doi: 10.1038/nature11908.

Ballhaus C.G., Berry R.F., Green D.H., 1991. Experimental calibration of the olivineorthopyroxene-spinel oxygen barometer- implications for oxygen fugacity in the Earth's upper mantle. Contributions to Mineralogy and Petrology 107, 27-40.

Ballhaus C., Frost BR., 1994. The generation of oxidised CO2-bearing basaltic melts from reduced $\mathrm{CH} 4$-bearing upper mantle sources. Geochim. Cosmochim. Acta 58, 4431-40

Behrens H., Gaillard F., 2006. Geochemical Aspects of Melts: Volatiles and Redox Behavior. Elements 2, 275-280. DOI: 10.2113/gselements.2.5.275.

Berry A. J., Danyushevsky L. V., O'Neill H. St C., Newville M., Sutton S.R., 2008. Oxidation state of iron in komatiitic melt inclusions indicates hot Archaean mantle. Nature 455, 960-963. DOI: 10.1038/nature07377.

Bezos A., Humler E., 2005. The Fe3+/_Fe ratios of MORB glasses and their implications for mantle melting. Geochim. Cosmochim. Acta 69, 711-25.

Botcharnikov R.E., Koepke J., Holtz F., McCammon C., Wilke M., 2005. The effect of water activity on the oxidation and structural state of Fe in a ferro-basaltic melt. Geochimica Cosmochimica Acta 69, 5071-5085.

Botcharnikov R.E., Linnen R.L., Holtz F., 2010. Solubility of Au in Cl- and S-bearing hydrous silicate melts, Geochimica et Cosmochimica Acta 74, 2396-2411

Burgisser A., Scaillet B., 2007. Redox evolution of degassing magma rising to the surface, Nature 445, 194-197.

Burnham A.D., Berry A.J., 2012. An experimental study of trace element partitioning between zircon and melt as a function of oxygen fugacity. Geochimica et Cosmochimica Acta 95, 196-212.

Brandon A.D., Draper D.S., 1996. Constraints on the origin of the oxidation state of mantle overlying subduction zones: An example from Simcoe, Washington, USA. Geochimica et Cosmochimica Acta 60, 1739-1749. 
Candela P.A., 1986. The evolution of aqueous vapor from silicate melts: effect on oxygen fugacity. Geochimica Cosmochimica Acta 50, 1205-1211.

Canil D., 1997. Vanadium partitioning and the oxidation state of Archaean Komatiite magmas. Nature 389, 842-845.

Canil D., 2002, Vanadium in peridotites, mantle redox and tectonic environments: Archean to present. Earth and Planetary Science Letters, 195, 75-90.

Canil D., O’Neill HStC., 1996. Distribution of ferric iron in some upper-mantle assemblages. J. Petrol. 37, 609-35.

Canil D., O’Neill H.StC., Pearson D.G., Rudnick R.L., McDonough W.F., et al., 1994. Ferric iron in peridotites and mantle oxidation states. Earth and Planetary Science Letters 123, 205-20.

Carmichael I.S.E., 1991, The redox states of basic and silicic magmas: a reflection of their source regions?. Contribution to Mineralogy and Petrology 106, 129-141.

Carmichael I.S.E., Ghiorso M.S., 1986. Oxidation-reduction relations in basic magma: a case for homogeneous equilibria. Earth and Planetary Science Letters 78, 200-210.

Carmichael I.S.E., Ghiorso M.S., 1990. The effect of oxygen fugacity on the redox state of natural liquids and their crystallizing phases, in, Nicholls J, Russell JK, eds., Modern Methods of Igneous Petrology: Understanding Magmatic Processes, Mineralogical Society of America Reviews in Mineralogy 24, 191-212.

Cartigny P., Pineau F., Aubaud C. and Javoy M., 2008. Towards a consistent mantle carbon flux estimate: Insights from volatile systematics $(\mathrm{H} 2 \mathrm{O} / \mathrm{Ce}, \delta \mathrm{D}, \mathrm{CO} 2 / \mathrm{Nb})$ in the North Atlantic mantle $\left(14^{\circ} \mathrm{N}\right.$ and $\left.34^{\circ} \mathrm{N}\right)$. Earth Planet. Sci. Lett. 265, 672-685.

Christie D.M., Carmichael I.S.E., Langmuir C.H., 1986. Oxidation state of mid-ocean ridge basalt glasses. Earth Planetary Science Letters 79, 397-411.

Coltorti M., Bonadiman C., Hinton R. W., Siena F., Upton B. G. J., 1999. Carbonatite Metasomatism of the Oceanic Upper Mantle: Evidence from Clinopyroxenes and Glasses in Ultramafic Xenoliths of Grande Comore, Indian Ocean. J. Petrology 40, 133-165. doi: 10.1093/petroj/40.1.133.

Connolly J.A.D., 2005. Computation of phase equilibria by linear programming: A tool for geodynamic modeling and its application to subduction zone decarbonation. Earth and Planetary Science Letters 236, 524-541. 
Cooper R.F, Fanselow J.B, Poker D.B, 1996. The mechanism of oxidation of a basaltic glass: Chemical diffusion of network-modifying cations. Geochimica et Cosmochimica Acta $60,3253-3265$.

Cottrell E., Kelley K.A., 2011. The oxidation state of Fe in MORB glasses and the oxygen fugacity of the upper mantle. Earth and Planetary Science Letters 305, 270-278.

Cottrell E., Kelley K.A., 2013. Redox Heterogeneity in Mid-Ocean Ridge Basalts as a Function of Mantle Source. Science 340, 1314-1317. doi: 10.1126/science.1233299.

Crabtree S.M., Lange R.A., 2012. An evaluation of the effect of degassing on the oxidation state of hydrous andesite and dacite magmas: a comparison of pre-and post-eruptive Fe2+ concentrations. Contrib. Mineral. Petrol. 163, 209-224.

Creighton S., Stachel T., Matveev S., Hofer H., McCammon C., Luth R.W., 2009. Oxidation of the Kaapvaal lithospheric mantle driven by metasomatism. Contribution to Mineralogy and Petrology 157, 491-504.

Dasgupta R., Hirschmann M.M., 2010. The deep carbon cycle and melting in Earth's interior. Earth Planet. Sci. Lett. 298, 1-13.

Dasgupta R., Mallik A., Tsuno K., Withers A.C., Hirth G., Hirschmann M.M., 2013, Carbon-dioxide-rich silicate melt in the Earth's upper mantle. Nature 493, 211-U222.

Debret B., Andreani M., Muñoz M., Bolfan-Casanova N., Carlut J., Nicollet C., Schwartz S., Trcera N., 2014. Evolution of Fe redox state in serpentine during subduction. Earth and Planetary Science Letters 400, 206-218.

Delano J.W., 2001. Redox history of the Earth's interior since similar to $3900 \mathrm{Ma}$ : Implications for prebiotic molecules. Orignis of Life and Evolution of the Biosphere 31, 311341.

de Moor J. M., Fischer T. P., Sharp Z. D., King P. L., Wilke M., Botcharnikov R. E., Cottrell E., Zelenski M., Marty B., Klimm K., Rivard C., Ayalew D., Ramirez C., Kelley K.A, 2013. Sulfur degassing at Erta Ale (Ethiopia) and Masaya (Nicaragua) volcanoes: Implications for degassing processes and oxygen fugacities of basaltic systems. Geochemistry, Geophysics, Geosystems 14, 1525-2027. doi: 10.1002/ggge.20255.

Dixon J. E., Clague D. A., Wallace P., Poreda R., 1997. Volatiles in alkalic basalts form the North Arch Volcanic Field, Hawaii: extensive degassing of deep submarine-erupted alkalic series lavas. Journal of Petrology 38, 911-939.

Edmonds, M., 2008. New geochemical insights into volcanic degassing. Phil. Trans. Math. Phys. Eng.Sci. 366, 4559-4579. 
Evans B.W., 2008, Control of the Products of Serpentinization by the (FeMg1)-Mg2 Exchange Potential of Olivine and Orthopyroxene, Journal of Petrology 49, 1873-1887.

Evans K.A., 2012. The redox budget of subduction zones. Earth-Science Reviews 113, 11-32.

Foley S.F., 2012. A reappraisal of Redox Melting in the Earth's Mantle as a function of tectonic steeing and time. Journal of petrology 52, 1363-1391. doi:10.1093/petrology/egq061.

Frost B.R., 1991. Introduction to oxygen fugacity and its petrologic importance. In Oxide Minerals: Petrologic and Magnetic Significance, ed. DH Lindsley, Rev. Mineral., 25:19.Washington, DC: Mineral. Soc. Am. 508 pp.

Frost B.R, Ballhaus C., 1998. Comment on "Constraints on the origin of the oxidation state of mantle overlying subduction zones: An example from Simcoe, Washington, USA". Geochimica Cosmochimica Acta 62, 329-331.

Frost D.J., McCammon C.A., 2008. The Redox State of Earth's Mantle, Annual Review in Earth and Planetary Sciences 36, 389-420.

Frost D.J., Liebske C., Langenhorst F., McCammon C.A., Trønnes R.G., et al., 2004. Experimental evidence for the existence of iron-rich metal in the Earth's lower mantle. Nature 248, 409-12.

Frost, D.J., Mann, U., Asahara, Y., Rubie, D.C. 2008. The redox state of the mantle during and just after core formation. Phil. Trans. R. Soc. A, 366, 4315-4337, doi:10.1098/rsta.2008.0147

Gaillard F., Scaillet B., Pichavant M., Beny, J.M., 2001. The effect of water and fO2 on the ferric-ferrous ratio of silicic melts. Chem. Geol. 174, 255-273.

Gaillard F., Scaillet B., Pichavant M., 2002. Kinetics of iron oxidation-reduction in hydrous silicic melts. American Mineralogist 87, 829-837.

Gaillard F., Pichavant M., Mackwell S., Scaillet B., Champallier R., Mac Cammon C., 2003a. Chemical transfers during redox exchange between H2-bearing vapor and iron-bearing melt. American mineralogist 88, 308-315.

Gaillard, F., Schmidt B., Mac Cammon C., Mackwell S., 2003b. Rate of hydrogen-iron redox exchange in silicate melts and glasses. Geochim. Cosmochim. Acta 67, 2427-2441.

Gaillard F., Malki M., Iacono-Marziano G., Pichavant M., Scaillet B., 2008. Carbonatite melts and electrical conductivity in the asthenosphere. Science 322, 1363-1365.

Gaillard F., Scaillet B., Arndt N.T., 2011. Atmospheric oxygenation caused by a change in volcanic degassing pressure. Nature 478, 229-232. 
Gaillard F., Scaillet B., 2009. The sulfur content in volcanic gases of Mars. Earth and Planetary Science Letters 279, 34-43.

Gaillard F., Michalski J., Berger G., McLennan S., Scaillet B., 2013. Geochemical reservoirs and timing of sulphur cycling on Mars. Space Science Reviews. Space Science Reviews, 174, 251-300.

Gaillard F. and Scaillet B., 2014. A theoretical framework for volcanic degassing chemistry in a comparative planetology perspective and implications for planetary atmospheres. Earth and Planetary Science Letters 403, 307-316.

Ganino C, Arndt NT, Zhou M-F, F. Gaillard, Chauvel C., 2008. Interaction of magma with sedimentary wall rock and magnetite ore genesis in the Panzhizhua mafic intrusion. Mineral. Deposita, DOI: 10.1007/s00126-008-0191-5.

Gerlach T.M., 1993. Oxygen buffering of Kilauea volcanic gases and the oxygen fugacity of Kilauea basalt. Geochimica et Cosmochimica Acta 57, 795-814.

Green, D.H., Falloon, T.J. and Taylor, W.R., 1987. In Magmatic Processes. Physicochemical principles, (B.O. Mysen, ed.), Geochem. Soc. London,

Greenwood R.C., Franchi I.A., Jambon A., Buchanan P.C., 2005. Widespread magma oceans on asteroidal bodies in the early solar system. Nature 435, 916-918.

Gudmundsson G., Wood B.J., 1995. Experimental tests of garnet peridotite oxygen barometry. Contrib. Mineral. Petrol. 119, 56-67.

Guillot S, Hattori K.H., de Sigoyer J., Nagler T., Auzende A-L., 2001. Evidence of hydration of the mantle wedge and its role in the exhumation of eclogites. Earth and Planetary Science Letters 193, 115-127.

Halevy I., Johnston D.T., Schrag D.P., 2010. Explaining the Structure of the Archean Mass-Independent Sulfur Isotope Record. Science 329, 204-207.

Hammouda T., 2003. High-pressure melting of carbonated eclogite and experimental constraints on carbon recycling and storage in the mantle. Earth and Planetary Science Letters $214,357-368$.

Hattori K., Takahash Y., Guillot S., Johanson B. 2005. Occurrence of arsenic (V) in forearc mantle serpentinites based on X-ray absorption spectroscopy study. Geochimica et Cosmochimica Acta 69, 5585-5596. 
Helo, C., Longpré M.-A., Shimizu N., Clague D. A., and Stix J., 2011. Explosive eruptions at mid-ocean ridges driven by $\mathrm{CO} 2$-rich magmas, Nature Geoscience 4, 260-263. doi:10.1038/ngeo1104.

Herzberg C., Condie, K., Korenaga, J., 2010. Thermal history of the Earth and its petrological expression. Earth and Planetary Science Letters 292, 79-88.

Holland H.D., 2002. Volcanic gases, black smokers, and the Great Oxidation Event, Geochimica Cosmochimica Acta 66, 3811-3826.

Holloway J.R., 2004. Redox reactions in seafloor basalts: possible insights into silicic hydrothermal systems. Chemical Geology 210, 225-230.

Honnorez J., 2003. Hydrothermal alteration vs. ocean-floor metamorphism. A comparison between two case histories: the TAG hydrothermal mound (Mid-Atlantic Ridge) vs. DSDP/ODP Hole 504B (equatorial East Pacific). C. R. Geosci., 335, 781-824. doi:10.1016/j.crte.2003.08.009

Hirschmann M. M., 2009. Ironing Out the Oxidation of Earth's Mantle. Science 325, 545-546. DOI: 10.1126/science. 1176882

Hirschmann M. M., 2012. Magma ocean influence on early atmosphere mass and composition. Earth and Planetary Science Letters 279, 48-57. doi: 10.1016/j.epsl.2012.06.015.

Hopkins M.D., Harrison T.M., Manning C. E., 2010. Constraints on Hadean geodynamics from mineral inclusions in N4 Ga zircons. Earth and Planetary Science Letters 298, 367-376.

Iacono-Marziano G., Gaillard F., Scaillet B., Pichavant M., Chiodini G., 2009. The role of non-mantle $\mathrm{CO} 2$ in the dynamic of volcano degassing: the Mt.Vesuvius exemple. Geology 37, 319-322; doi: 10.1130/G25446A.

Iacono-Marziano G., Marecal V., Pirre M., Gaillard F., Arteta J., Scaillet B., Arndt N.T., 2012a. Gas emissions due to magma-sediment interactions during flood magmatism at the Siberian Traps: gas dispersion and environmental consequences. Earth and Planetary Science Letters 357, 308-318.

Iacono-Marziano G., Gaillard F., Scaillet B., Polozov A.G., Marecal V., Pirre M., Arndt N.T., 2012b. Extremely reducing conditions reached during basaltic intrusion in organic matter-bearing sediments. Earth and Planetary Science Letters 357, 319-326.

Iacono-Marziano G., Morizet Y., Le Trong E., Gaillard F., 2013. New experimental data and semi-empirical parameterization of $\mathrm{H} 2 \mathrm{O}-\mathrm{CO} 2$ solubility in mafic melts. Geochimica et Cosmochimica Acta 97, 145-157. 
Jambon, A., 1994. Earth degassing and large-scale geochemical cycling of volatile elements Reviews in Mineralogy and Geochemistry 30, 479-517.

Javoy M., 1995. The integral enstatite chondrite model of the Earth. Geophysical Research Letters Volume 22, 2219-2222.

Javoy M., Kaminski E., Guyot F., Andrault D., Sanloup, C., Moreira M., Labrosse S., Jambon A., Agrinier P., Davaille A., Jaupart C., 2010. The chemical composition of the Earth: Enstatite chondrite models. Earth and Planetary Science Letters 293, 259-268.

Jégo S., Pichavant M., 2012. Gold solubility in arc magmas: Experimental determination of the effect of sulfur at $1000{ }^{\circ} \mathrm{C}$ and $0.4 \mathrm{GPa}$. Geochimica et Cosmochimica Acta 84, 560592.

Jégo S., Dasgupta R., 2013. Fluid-present melting of sulfide-bearing ocean crust: Experimental constraints on the transport of sulfur from slab to mantle wedge. Geochimica et Cosmochimica Acta 110, 106-134. doi:http://dx.doi.org/10.1016/j.gca.2013.02.011.

Jenner F. E., O’Neill H. ST. C., Arculus R. J., Mavrogenes J. A., 2010. The Magnetite Crisis in the Evolution of Arc-related Magmas and the Initial Concentration of $\mathrm{Au}, \mathrm{Ag}$ and $\mathrm{Cu}$ Journal of Petrology 51, 2445-2464. doi:10.1093/petrology/egq063.

Jenner F. E., and. O’Neill H.St.C., 2012. Analysis of 60 elements in 616 ocean floor basaltic glasses, Geochem. Geophys. Geosyst. 13, Q02005, doi:10.1029/2011GC004009.

Jugo P.J., 2009. Sulfur content at sulfide saturation in oxidized magmas. Geology 37, 415-418, doi: 10.1130/G25527A.1.

Jugo P.J., Wilke M., Botcharnikov R.E., 2010. Sulfur K-edge XANES analysis of natural and synthetic basaltic glasses: Implications for $\mathrm{S}$ speciation and $\mathrm{S}$ content as function of oxygen fugacity. Geochimica and Cosmochimica Acta 74, 5926-5938. doi: 10.1016/j.gca.2010.07.022.

Kasting J.F., Eggler D.H., Raeburn S.P., 1993. Mantle redox evolution and the oxidation state of the Archean atmosphere. Journal of Geology 101, 245-257.

Kelley K.A., Cottrell E., 2009, Water and the Oxidation State of Subduction Zone Magmas, Science 325, 605-607.

Kelley K.A., Cottrell E., 2012. The influence of magmatic differentiation on the oxidation state of Fe in a basaltic arc magma. Earth and Planetary Science Letters 329-330, 109-121.

Keller B., Schoene B., 2012. Statistical geochemistry reveals disruption in secular lithospheric evolution about 2.5 Gyr ago, Nature 485, 490-493 doi:10.1038/nature11024. 
Kress V.C., Carmichael I. S. E., 1991. The compressibility of silicate liquids containing $\mathrm{Fe}_{2} \mathrm{O}_{3}$ and the effect of composition, temperature, oxygen fugacity and pressure on their redox states. Contributions to Mineralogy and Petrology 108, 82-92.

Kump L.R., Barley M.E., 2007. Increased subaerial volcanism and the rise of atmospheric oxygen 2.5 billion years ago, Nature 448, 1033-1036.

Lee C-T.A., Luffi P., Le Roux V., Dasgupta R., Albarede F., Leeman W.P., 2010. The redox state of arc mantle using $\mathrm{Zn} / \mathrm{Fe}$ systematics. Nature 468, 681-685.

Lee C.-T. A., Leeman W. P., Canil D. \& Li Z.-X. A., 2005. Similar V/Sc Systematics in MORB and Arc Basalts: Implications for the Oxygen Fugacities of their Mantle Source Regions, Journal of Petrology 46, 2313-2336.

Lee C.-T.A., Luffi P., Chin E. J., Bouchet R., Dasgupta R., Morton D. M., Le Roux V., Yin Q.-Z., Jin D., 2012. Copper systematics in arc magmas and implications for crust-mantle differentiation. Science 336, 64-68.

Lecuyer C., Ricard Y., 1999. Long-term fluxes and budget of ferric iron: implication for the redox states of the Earth's mantle and atmosphere. Earth and Planetary Science Letters $165,197-211$.

Li Z.X.A., Lee C.T.A., 2004. The constancy of upper mantle $\mathrm{fO}_{2}$ through time inferred from V/Sc ratios in basalts, Earth and Planetary Science Letters 228, 483-493.

Li Z-XA, Lee C-T.A., 2006. Geochemical investigation of serpentinized oceanic lithospheric mantle in the Feather River Ophiolite, California: Implications for the recycling rate of water by subduction. Chemical Geology 235, 161-185.

Lyons T.W., Gill B.C., 2010. Ancient Sulfur Cycling and Oxygenation of the Early Biosphere, Elements 6, 93-99.

Luth R.W., Virgo D., Boyd F.R., Wood B.J., 1990. Ferric iron in mantle-derived garnets. Contrib. Miner. Petrol. 104, 56-72.

Mallman G., and O’Neill H.StC., 2009. The Crystal/Melt Partitioning of V during Mantle Melting as a Function of Oxygen Fugacity Compared with some other Elements (Al, P, Ca, Sc,Ti, Cr, Fe, Ga, Y, Zr and Nb). Journal of Petrology 50, 1765-1794.

Mallmann, G. and O'Neill, H. StC., 2013. Calibration of an empirical thermometer and oxybarometer based on the partitioning of Sc, Y and V between olivine and silicate melt', Journal of Petrology 54, 933-949.

Malaspina N., Poli S., Fumagalli P., 2008. The Oxidation State of Metasomatized Mantle Wedge: Insights from C-O-H-bearing Garnet Peridotite, Journal of Petrology 50, 1533-1552. 
Martel C., Pichavant M., Holtz F., Scaillet B., Bourdier J.L., Traineau H., 1999. Effects of $\mathrm{f}_{\mathrm{O} 2}$ and $\mathrm{H}_{2} \mathrm{O}$ on andesite phase relations between 2 and 4 kbar. J. Geophys. Res. 104, 29453-29470.

Mathez E.A., 1984. Influence of degassing on oxidation states of basaltic magmas. Nature 310, $371-375$.

McCammon C.A., 1997. Perovskite as a possible sink for ferric iron in the lower mantle. Nature 387, 694-696.

McCammon C.A., Kopylova M.G., 2004. A redox profile of the Slave mantle and oxygen fugacity control in the cratonic mantle. Contrib. Miner. Petrol. 148, 55-68.

McCammon CA., 2005. Mantle oxidation state and oxygen fugacity: constraints on mantle chemistry, structure and dynamics. In Earth's Deep Mantle: Structure, Composition, and Evolution, ed. RD van der Hilst, J Bass, J Matas, J Trampert, Geophys. Monogr. Ser. 160, 221-42. Washington, DC: Am. Geophys. Union.350 pp.

McCammon C.A., Griffin W.L., Shee S.R., O’Neill HStC., 2001. Oxidation during metasomatism in ultramafic xenoliths from the Wesselton kimberlite, South Africa: implications for the survival of diamond. Contrib. Miner. Petrol. 141, 287-96.

Marty B., 2012. The origins and concentrations of water, carbon, nitrogen and noble gases on Earth. Earth and Planetary Science Letters 313, 56-66.

Menand T., Phillips J. C., 2007. Gas segregation in dykes and sills. J. Volcanol. Geotherm. Res. 159, 393-408.

Menzies M. A., 1983. in Continental Basalts and Mantle Xenoliths, Mantle ultramafic xenoliths in alkaline magmas: evidence for mantle heterogeneity modified by magmatic activity, eds Hawkesworth C. J., Norry M. J. (Shiva, Nantwich), pp 92-110.

Métrich N., Schiano P., Clocchiatti R., Maury R.C., 1999. Transfer of sulfur in subduction settings: an example from Batan Island (Luzon volcanic arc, Philippines). Earth and Planetary Science Letters 167, 1-14.

Métrich N., Berry A. J., O’Neill H. St.C., Susini J., 2009. Oxidation state of sulphur in synthetic and natural glasses determined by X-ray absorption spectroscopy. Geochim. Cosmochim. Acta. 73, 2382-2399. DOI: 10.1016/j.gca.2009.01.025.

Moussallam Y., Oppenheimer C., Scaillet B., Gaillard F., Kyle P., Peters N., Hartley M.,E., Berlo K., Donovan A, 2014. Tracking the changing oxidation state of Erebus magmas, from mantle to surface, driven by magma ascent and degassing. Earth and Planetary Science Letters 393, 200-209. http://dx.doi.org/10.1016/j.epsl.2014.02.055. 
Mungall J.E., 2002. Roasting the mantle: slab melting and the genesis of major Au and Au-rich Cu deposits. Geology 30, 915-918.

Mungall J.E., Hanley J.J., Arndt N.T., Debecdelievre A., 2006. Evidence from meimechites and other low-degree mantle melts for redox controls on mantle-crust fractionation of platinum-group elements. PNAS 103, 12695-12700.

Miyashiro A. 1974. Volcanic rock series in island arcs and active continental margins. American Journal of Science 274, 321-355.

O’Neill H. St. C., Rubie D. C., Canil D., Geiger C. A., Ross C. R., Seifert F., Woodland A. B., 1993. Ferric iron in the upper mantle and in Transition Zone assemblages: Implications for relative oxygen fugacities in the mantle. In: Rubie, D. C. (ed.) Evolution of the Earth and Planets. American Geophysical Union, Geophysical Monograph 74, 7473-88.

O’Reilly S.Y., Griffin W.L., 2012. Mantle Metasomatism. In D.E. Harlov and H. Austrheim (eds.) Metasomatism and the Chemical Transformation of Rock, Lecture Notes in Earth System Sciences, DOI 10.1007/978-3-642-28394-9_12. Springer-Verlag Berlin Heidelberg 2012. 467-528.

Padron-Navarta J.A., Sanchez-Vizcaino V.L., Garrido C.J., Gomez-Pugnaire M.T., 2011. Metamorphic Record of High-pressure Dehydration of Antigorite Serpentinite to Chlorite Harzburgite in a Subduction Setting (Cerro del Almirez, Nevado-Filabride Complex, Southern Spain), Journal of Petrology 52, 2047-2078. DOI: 10.1093/petrology/egr039.

Parkinson I.J., Arculus R.J., Eggins Æ.S.M., 2003. Peridotite xenoliths from Grenada, Lesser Antilles Island Arc. Contrib Mineral Petrol 146, 241-262.

Pawley, A. R., Holloway, J. R., \& McMillan, P. F., 1992. The effect of oxygen fugacity on the solubility of carbon-oxygen fluids in basaltic melt. Earth and Planetary Science Letters $110,213-225$.

Pichavant M., Mysen B. O., Macdonald R. 2002. Source and H2O content of high-MgO magmas in island arc settings - An experimental study on primitive calk-alkaline basalts from St.Vincent, Lesser Antilles.. Geochimica et Cosmochimica Acta 66, 2193-2209. 10.1016/S0016-7037(01)00891-2

Pichavant M., McDonald R., 2007. Crystallization of primitive basaltic magmas at crustal pressures and genesis of the calc-alkaline igneous suite: experimental evidence from $\mathrm{St}$ Vincent, Lesser Antilles arc. Contrib. Mineral. Petrol. 154, 535-558.

Pichavant M, Brugier, Y, Di Muro A (in press) Petrological and experimental constraints. In: Active Volcanoes of the Southwest Indian Ocean: Piton de la Fournaise and Karthala, P Bachélery, A Di Muro, J-F Lénat, L Michon (eds). Springer Monograph series. 
Pilet, S., Baker, M. B. and Stolper, E. M., 2008. Metasomatized lithosphere and the origin of alkaline lavas. Science 320, 916-919.

Poli S., Franzolin E., Fumagalli P., Crottini A., 2009. The transport of carbon and hydrogen in subducted oceanic crust: An experimental study to 5 GPa. Earth and Planetary Science Letters 278, 350-360.

Prouteau G., Scaillet, B., 2012. Experimental Constraints on Sulphur Behaviour in Subduction Zones: Implications forTTG and adakite production and the global sulphur cycle since the Archean . Journal of Petrology (2012) doi: 10.1093/petrology/egs067.

Richards J., 2015. The oxidation state, and sulfur and $\mathrm{Cu}$ contents of arc magmas: implications for metallogeny. Lithos (in press). doi:10.1016/j.lithos.2014.12.011

Ricolleau A., Fei Y., Corgne A., Siebert J., Badro J., 2011. Oxygen and silicon contents of Earth's core from high pressure metal-silicate partitioning experiments. Earth Planet. Sci. Lett. 310, 409-421.

Roeder P.L., Thornber C., Poustovetov A., Grant, A., 2003. Morphology and composition of spinel in Pu'u'O'o lava (1996-1998), Kilauea volcano, Hawaii. Journal of Volcanology and Geothermal Research 123, 245-265.

Rhodes J. M., Vollinger M.J., 2005. Ferric/ferrous ratios in 1984 Mauna Loa lavas: a contribution to understanding the oxidation state of Hawaiian magmas. Contributions to Mineralogy and Petrology 149, 666-674.

Rohrbach A., Ballhaus C., Golla-Schindler U., Ulmer P., Kamenetsky V.S., Kuzmin D.V., 2007. Metal saturation in the upper mantle. Nature 449, 456-458.

Rohrbach et al. 2011, Experimental evidence for a reduced metal-saturated upper mantle. J. Petrol. 52, 717-731.

Rohrbach A., Schmidt M.W., 2011. Redox freezing and melting in the Earth/'s deep mantle resulting from carbon-iron redox coupling. Nature 472, 209-212.

Rohrbach A., Ghosh S., Schmidt M.W., Wijbrans C.H., Klemme S., 2014. The stability of $\mathrm{Fe}-\mathrm{Ni}$ carbides in the Earth's mantle: Evidence for a low $\mathrm{Fe}-\mathrm{Ni}-\mathrm{C}$ melt fraction in the deep mantle. Earth and Planetary Science Letters 388, 211-221.

Rowe M. C., Kent A. J. R., Nielsen R. L., 2009. Subduction Influence on Oxygen Fugacity and Trace and Volatile Elements in Basalts Across the Cascade Volcanic Arc. Journal of Petrology 50, 61-91. 
Rubie, D. C., Melosh, H. J., Reid, J. E., Liebske, C., \& Righter, K., 2003. Mechanisms of metal-silicate equilibration in the terrestrial magma ocean. Earth and Planetary Science Letters, 205, 239-255.

Rubie, D.C., Frost, D.J., Mann, U., Asahara, Y., Tsuno, K., Nimmo, F., Kegler, P., Holzheid, A., Palme, H., 2011. Heterogeneous accretion, composition and core-mantle differentiation of the Earth. Earth and Planetary Science Letters 301, 31-42, doi: 10.1016/j.epsl.2010.11.030

Russell M.J., Nitschke W., Branscomb E., 2013. The inevitable journey to being. Phil. Trans. R. Soc. B. 368, no. 162220120254.

Sato M.,1978. Oxygen fugacity of basaltic magmas and the role of gas-forming elements. Geophysical Research Letters 5, 447-449

Scaillet, B., Clémente, B., Evans, B. W., \& Pichavant, M., 1998. Redox control of sulfur degassing in silicic magmas. Journal of Geophysical Research: Solid Earth (1978-2012), 103(B10), 23937-23949.

Scaillet B., Gaillard F., 2011. Redox state of early magmas, Nature 480, 48-49.

Scaillet B., Pichavant. M., Roux J., Humbert G., Lefevre A., 1992 Improvements of the Shaw membrane technique for measurement and control of f., at high temperatures and pressures. American Mineralogist 77, 647-655.

Schmidt B.C., Holtz F., Scaillet B., Pichavant M., 1997. The influence of $\mathrm{H}_{2} \mathrm{O}-\mathrm{H}_{2}$ fluids and redox conditions on melting temperatures in the haplogranite system. Contributions to Mineralogy and Petrology 126, 386-400.

Schmidt M.W., and Poli S., 1998. Experimentally based water budgets for dehydrating slabs and consequences for arc magma generation, Earth and Planetary Science Letters 163, 361-379.

Shirayev A.A., Gaillard F., 2014. Local redox buffering by carbon at low pressures and the formation of moissanite - natural SiC. European journal of mineralogy. 26, 53-59. DOI: 10.1127/0935-1221/2013/0025-2339.

Sifre D., Gardes E., Massuyeau M., Hashim L., Hier-Majumder S., Gaillard F., 2014. Electrical conductivity during incipient melting in the oceanic low-velocity zone. Nature 509, 81 - 85. DOI: 10.1038/nature13245.

Sisson T. W., and Grove T. L., 1993. Experimental investigations of the role of $\mathrm{H}_{2} \mathrm{O}$ in calc-alkaline differentiation and subduction zone magmatism. Contrib. Mineral. Petrol. 113, 143-166. 
Sleep N.H., Windley B.F., 1982. Archean plate-tectonics- constraints and inferences, Journal of Geology 90, 363-379.

Sleep N., Bird D.K., Pope E.C., 2011. Serpentinite and the dawn of life. Phil. Trans. R. Soc. B 366, 2857-2869. doi:10.1098/rstb.2011.0129.

Stagno V., Frost D.J., 2010. Carbon speciation in the asthenosphere: Experimental measurements of the redox conditions at which carbonate-bearing melts coexist with graphite or diamond in peridotite assemblages. Earth Planet. Sci. Lett. 30,72-84.

Stagno V., Ojwang D.O., McCammon C.A., Frost D.J., 2013. The oxidation state of the mantle and the extraction of carbon from Earth's interior. Nature 493, 84-87.

Stamper C.C., Melekhova E., Blundy J.D., Arculus R.J., Humphreys M.C.S., Brooker R.A., 2014. Oxidised phase relations of a primitive basalt from Grenada, Lesser Antilles. Contributions to Mineralogy and Petrology 167, 1 - 20. DOI: 10.1007/s00410-013-0954-6.

Takafuji, N., Hirose, K., Ono, S., Xu, F., Mitome, M., \& Bando, Y. 2004. Segregation of core melts by permeable flow in the lower mantle. Earth and Planetary Science Letters, 224, 249-257.

Tatsumi Y, Suzuki T., 2009. Tholeiitic vs Calc-alkalic Differentiation and Evolution of Arc Crust: Constraints from Melting Experiments on a Basalt from the Izu-Bonin-Mariana Arc. Journal of Petrology 50, 1575-1603. doi: 10.1093/petrology/egp044

Trail D., Watson E.B., Tailby, N.D., 2011. The oxidation state of Hadean magmas and implications for early Earth's atmosphere. Nature 480, 79-82.

Uenver-Thiele L., Woodland A.B., Downes H., Altherr R., 2014. Oxidation State of the Lithospheric Mantle below the Massif Central, France. Journal of Petrology 55, 2457-2480. doi: 10.1093/petrology/egu063

Wallace P.J., 2005. Volatiles in subduction zone magmas: concentrations and fluxes based on melt inclusion and volcanic gas data. Journal of Volcanology and Geothermal Research 140, 217-240.

Wallace M.E., Green D.H., 1988. An experimental determination of primary carbonatite magma composition. Nature 335, 343-346.

Walter M.J., 1998. Melting of garnet peridotite and the origin of komatiite and depleted lithosphere. Journal of Petrology 39, 29-60.

Walter M.J., Tronnes R.G., 2004. Early Earth differentiation. Earth and Planetary Science Letters 225, 253-269. 
Watson E. B., Harrison T. M., 2005. Zircon Thermometer Reveals Minimum Melting Conditions on Earliest Earth. Science 308, 841-844. DOI: 10.1126/science.1110873

Wilke M., 2005. Fe in magma - An overview. Annals of Geophysics 48, 609-617.

Williams H.M., Wood B.J., Wade J., Frost D. \& Tuff J., 2012. Isotopic evidence for internal oxidation of the Earth's mantle during accretion. Earth and Planetary Science Letters 321-322, 54-63.

Wood B.J., Bryndzia L.T., Johnson K.E., 1990. Mantle oxidation state and its relationship to tectonic environment and fluid speciation. Science 248, 337-45.

Wood B.J., Walter M.J., Wade J., 2006. Accretion of the Earth and segregation of its core. Nature 441, 825-33.

Woodland A.B., Kornprobst J., McPherson E., Bodinier J-L., Menzies M.A., 1996. Metasomatic interactions in the lithospheric mantle. Petrologic evidence from the Lherz massif, French Pyrenees. Chem. Geol. 134, 83-112.

Woodland A.B., Koch M., 2003. Variation in oxygen fugacity with depth in the upper mantle beneath the Kaapvaal craton, Southern Africa. Earth and Planetary Science Letters 24, 295-310.

Yang X., Gaillard F., Scaillet B., 2014. A relatively reduced Hadean continental crust and implications for the early atmosphere and crustal rheology. Earth and Planetary Science Letters 393, 210-219. DOI: 10.1016/j.epsl.2014.02.056.

Yaxley G.M., Berry A.J., Kamenetsky V.S., Woodland A.B., Golovin A.V., 2012. An oxygen fugacity profile through the Siberian Craton - Fe K-edge XANES determinations of $\mathrm{Fe} 3+/ \sum \mathrm{Fe}$ in garnets in peridotite xenoliths from the Udachnaya East kimberlite. Lithos 140$141,142-151$.

Yoshino T., Walter M. J. and Katsura T., 2003. Core formation in planetesimals triggered by permeable flow. Nature 422, 154-157.

Zajacz Z., Candela P. A., Piccoli P.M., Sanchez-Valle C., Walle M., 2013. Solubility and partitioning behavior of $\mathrm{Au}, \mathrm{Cu}, \mathrm{Ag}$ and reduced $\mathrm{S}$ in magma. Geochimica et Cosmochimica Acta 112 (2013) 288-30

Zimmer, M. M. et al., 2010. The role of water in generating the calc-alkaline trend: New volatile data for Aleutian magmas and a new Tholeiitic Index. Journal of Petrology 51, 2411 2444. 
Acknowledgments- This work, part of the ElectroLith project, benefited from funding by the European Research Council (ERC project \#279790) and the French agency for research (ANR project \# 2010 BLAN62101). We acknowledge the careful reviews from Liz Cottrell, Arno Rohrbach and Cin-Ty Lee and the editorial handling by Carmen Sanchez Valle, Sujoy Ghosh, Tim Horscroft and Klaus Mezger.

\section{Figure captions:}

Figure 1: Oxygen fugacity of the Earth's mantle vs. time (modified after Scaillet and Gaillard, 2012). The time is indicated using a non-linear scale from the beginning of the solar system. The time scale is split in three epochs: 1, is the core-mantle regime starting from the oxygen fugacity of enstatite chondrites and progressively shifting to oxidizing conditions by internal-oxidation processes (see 2.1.); 2, is the mantle regime starting with the disproportionation in the lower mantle + convective mixing with the upper mantle leading to the self-oxidation (see 2.1.), the zircon era (see 2.3.) and the basaltic records (see 2.2.); 3, illustrates the crust-mantle regime, with the onset of arc-magmatism (see 3.4. and 3.6.).

Figure 2: The composition of volcanic gases in equilibrium with a basalt at 1 bar as a function of oxygen fugacity. The printed C-H-O-S concentration corresponds to the bulk content (melt+gas), which is equivalent to the C-H-S abundances in undegassed MORBs. The sulfur content in the basalt is also shown as a function of oxygen fugacity on the right hand side vertical axis. The upper (A) and lower (B) panels respectively indicate volatiles depleted and enriched MORB after Marty (2012). The $\mathrm{fO}_{2}$ ranges for most magmatic types, including the primordial magma ocean, and for the upper mantle are shown in the box at the top.

Figure 3A: The composition of magmatic gases produced by the Hadean granitic melts as a function of pressure (A) and temperature (B). (A)The pre-degassed melt contains $3 \mathrm{wt} \%$ $\mathrm{H}_{2} \mathrm{O}$ and $500 \mathrm{ppm} \mathrm{CO}_{2}$ at $800^{\circ} \mathrm{C}$. Graphite saturation is imposed at all conditions. This figure illustrates well the predominance of methane as a magmatic gas species at pressure $>100$ bar, whereas the speciation changes to $\mathrm{CO}-\mathrm{H}_{2}$ dominated at shallower conditions.(B) The composition of magmatic gases produced by the Hadean granitic melts as a function of temperature. The pre-degassed melt contains $3 \mathrm{wt} \% \mathrm{H}_{2} \mathrm{O}$ and $500 \mathrm{ppm} \mathrm{CO}_{2}$ and all calculations are done at $\mathrm{P}=100$ bar. Graphite saturation is imposed at all conditions. This figure illustrates well the predominance of methane as a magmatic gas species at temperatures $<850^{\circ} \mathrm{C}$, whereas the speciation changes to $\mathrm{CO}-\mathrm{H}_{2}$ dominated species at higher temperatures. 
Figure 4: Mantle oxygen fugacity vs. depth (right panel) and its expected impact on the redox state of Archean magma source regions (left and right). The $\mathrm{fO}_{2}$ vs depth plot is after Stagno et al. (2013) as expected from the garnet-olivine-orthopyroxene equilibrium (see also Rohrbach and Schmidt, 2011). The depth of Archean vs. present-day magma source regions is obtained using an Archean adiabatic depth-temperature path (Herzberg et al., 2010). The temperature-depth region for Komatiites is from Walter (1998). The C-CO redox buffer (green curve), that defines the coexistence of diamond and $\mathrm{CO}_{2}$-bearing melt (for $\mathrm{XCO}_{2}$ in melt $=0.2$ ), is calculated after Stagno and Frost (2010).

Figure 5: Conceptual figure illustrating the impact of mantle partial melting on the oxygen fugacity of the solid residue (depleted in incompatible elements) and the equilibrium melt (enriched in incompatible elements). The system should become increasingly reduced as partial melting proceeds. Small degree of partial melting must produce oxidized melts, which must reflect the oxidation state of the asthenosphere (see section 3.3.). The dashed horizontal lines illustrate variable degrees of partial melting $(1,10,30 \%)$.

Figure 6: The effect of fluid assimilation on the oxygen fugacity of a basalt. The basalt is defined at $1300^{\circ} \mathrm{C}, 600 \mathrm{MPa}$ (to remain in the domain of calibration of the model by IaconoMarziano et al., 2013); $\mathrm{H}_{2} \mathrm{O}$ content is $0.1 \mathrm{wt} \%$ and $\mathrm{CO}_{2}$ is $0.4 \mathrm{wt} \%$. Several assimilated fluids are considered from pure hydrous fluid $\left(\mathrm{H}_{2} \mathrm{O}\right), \mathrm{SO}_{2}$-bearing hydrous fluid and $\mathrm{SO}_{3}$-bearing fluids (up to $20 \% \mathrm{SO}_{3}$ ). The most efficient oxidant (that is, its assimilation lead to $\mathrm{fO}_{2}>$ $\mathrm{FMQ}+1)$ is $\mathrm{SO}_{3}$-bearing fluids. Based on this, we suggest that the assimilation of oxidized fluids derived from the plunging slab and rising through the mantle wedge may well reconcile the observation that arc-magma and the fluids deriving from the slab are oxidized but primary arc basalts do not bear evidence for high $\mathrm{fO}_{2}$. Such calculation cannot yet be operated at 1.5 $\mathrm{GPa}$ because of calibration issues at such pressure in the $\mathrm{C}-\mathrm{O}-\mathrm{H}-\mathrm{S}$ system, but the broad conclusion is not expected to change: Only $\mathrm{SO}_{3}$-rich fluids can be the oxidizing agent, whether it is a hydrous or a silicate fluid.

Figure 7: The effect of fluid phase loss on the oxygen fugacity of a rising basalts. The calculations are performed on relatively water-rich melts as expected for arc-magmas. Three pre-degassing redox conditions are considered from moderately reduced (FMQ-0.3) to moderately oxidized (FMQ+1.3). In all simulated cases, we show the closed-system evolution (gas and melt equilibrate together along the entire ascent) and the open-system evolution (the gas is expelled as it reaches $0.1 \mathrm{wt} . \%$ of the bulk system). As shown in the discussion (section 3.5.) the loss of the fluid phase and subsequent decompression and degassing induce a progressive oxidation of the system. This self-oxidation is of about $1 \mathrm{log}$-unit at low initial $\mathrm{fO}_{2}$ and decreases to $0.3 \mathrm{log}$-unit at the uppermost oxygen fugacity considered. Vapor loss can induce a moderate oxidation of the system, but it can hardly explain why arc-magmas are oxidized.

Figure 8: The speciation of iron and sulfur in basaltic melts as a function of oxygen fugacity and its impact on the redox evolution of basalts upon closed-system degassing. The speciation of iron moderately changes with changing $\mathrm{fO}_{2}$ whereas the $\mathrm{S}^{6+} / \mathrm{S}_{\text {tot }}$ ratio abruptly 
shifts from 0 to 1 in the $\mathrm{fO}_{2}$ range FMQ+0.5 to FMQ+1.5 (Jugo et al., 2010). The redox evolution of basalts during decompression-degassing as a function of initial $\mathrm{fO}_{2}$ diverges from a pre-degassing $\mathrm{fO}_{2}$ being on either flank of the S-speciation curve. The volatile contents of pre-degassing magmas increase from MORB (1500 ppm $\mathrm{H}_{2} \mathrm{O}-1500 \mathrm{ppm} \mathrm{CO}_{2}$ ) to arc magmas ( $3 \mathrm{wt} \% \mathrm{H}_{2} \mathrm{O}-2000 \mathrm{ppm} \mathrm{CO}_{2}$ ), but the diverging trends results from the difference of sulfur redox state between the melt (-II, +VI) and the gas (mainly +IV) (see section 3.5.).

Figure 9: The redox geodynamics at subduction zones. This simplified figure illustrates (1) the hydrothermal alterations of the oceanic lithosphere, triggering an oxidation of $\mathrm{Fe}$, the deposition $\mathrm{C}$ as carbonates, and the precipitation of $\mathrm{S}$ as sulfides mainly and (2) the fate of these elements during metamorphic and melting reactions along the subduction geotherms. The curves in red indicate a transfer resulting in an oxygen gain for the mantle (for iron and carbon), whereas the green curve shows a reducing effect (for sulfur), but this reducing effect is relative in that it means a less oxidative effect. See section 3.6. 


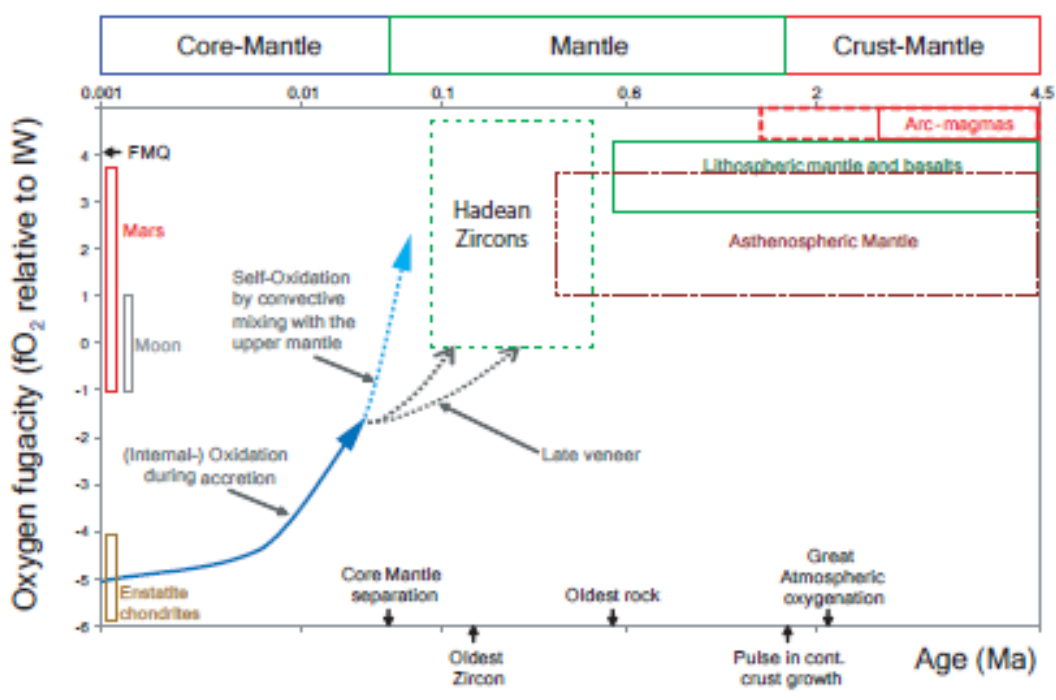




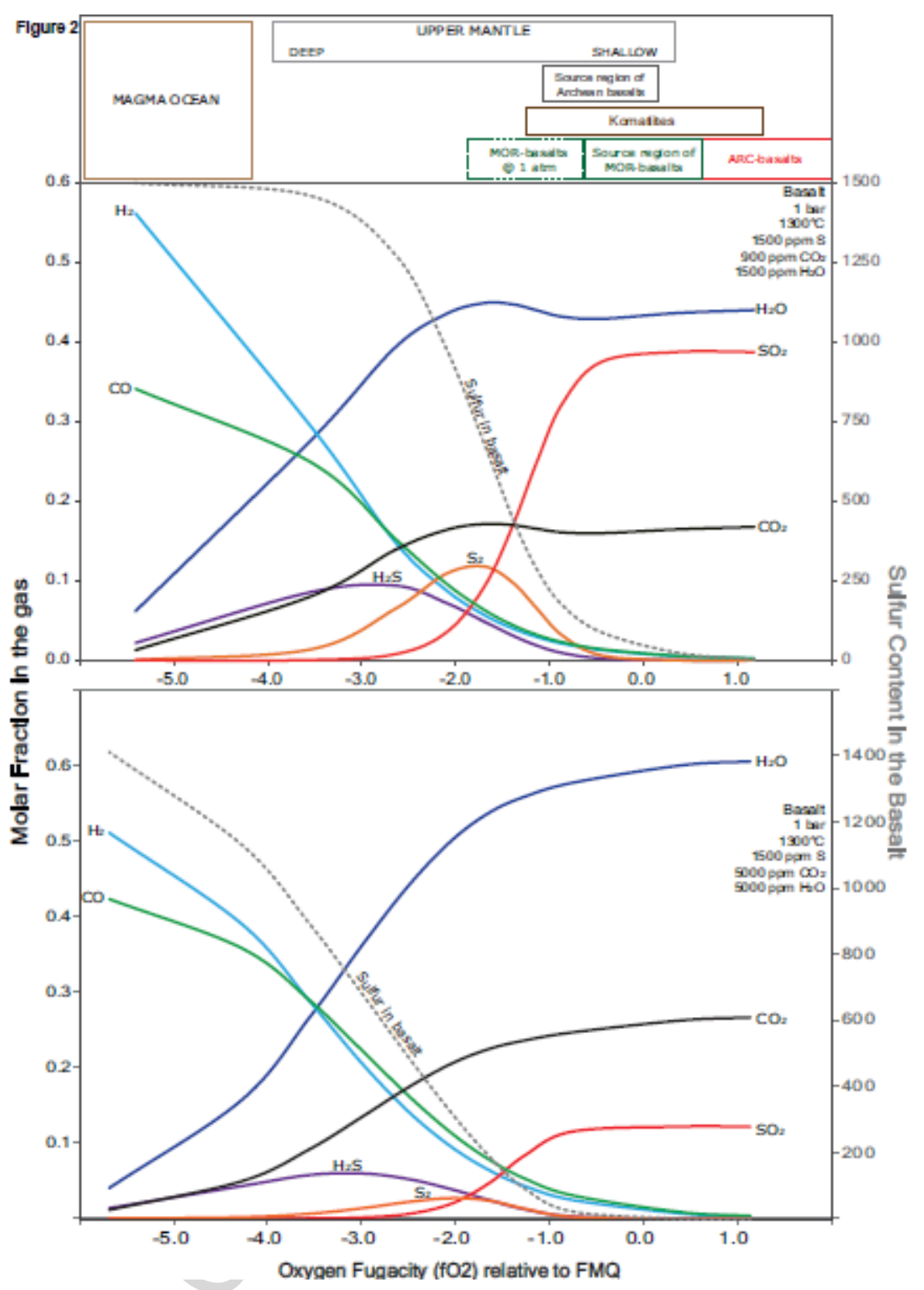


Figure $3 a$

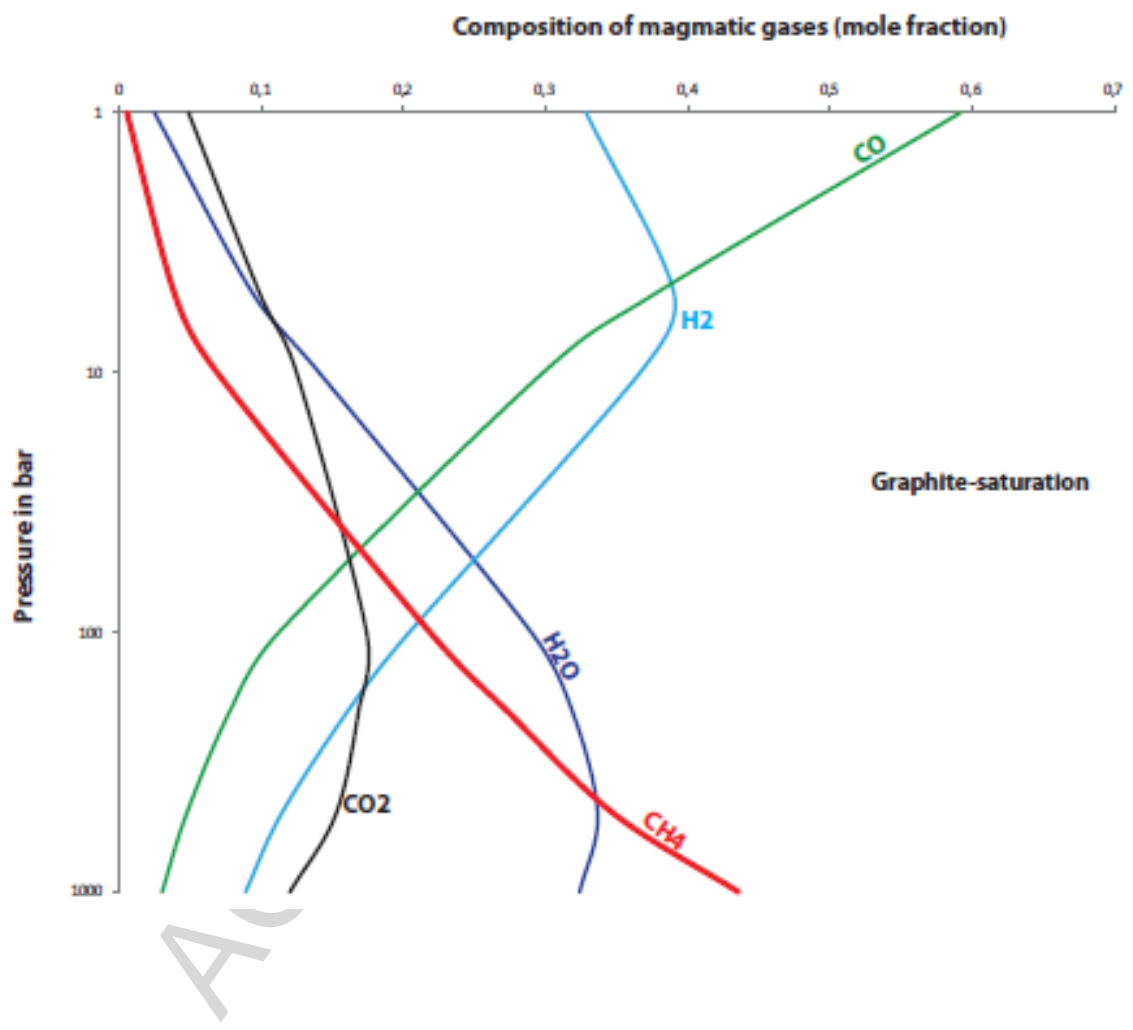


Figure 38

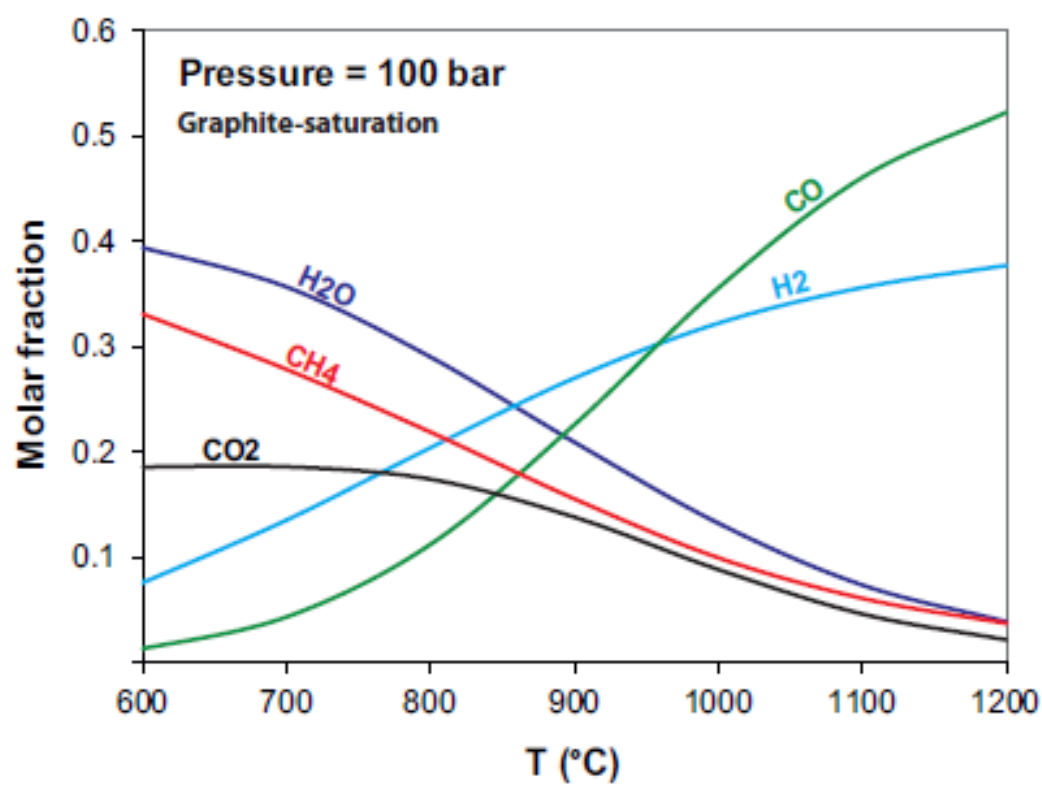


Figure 4

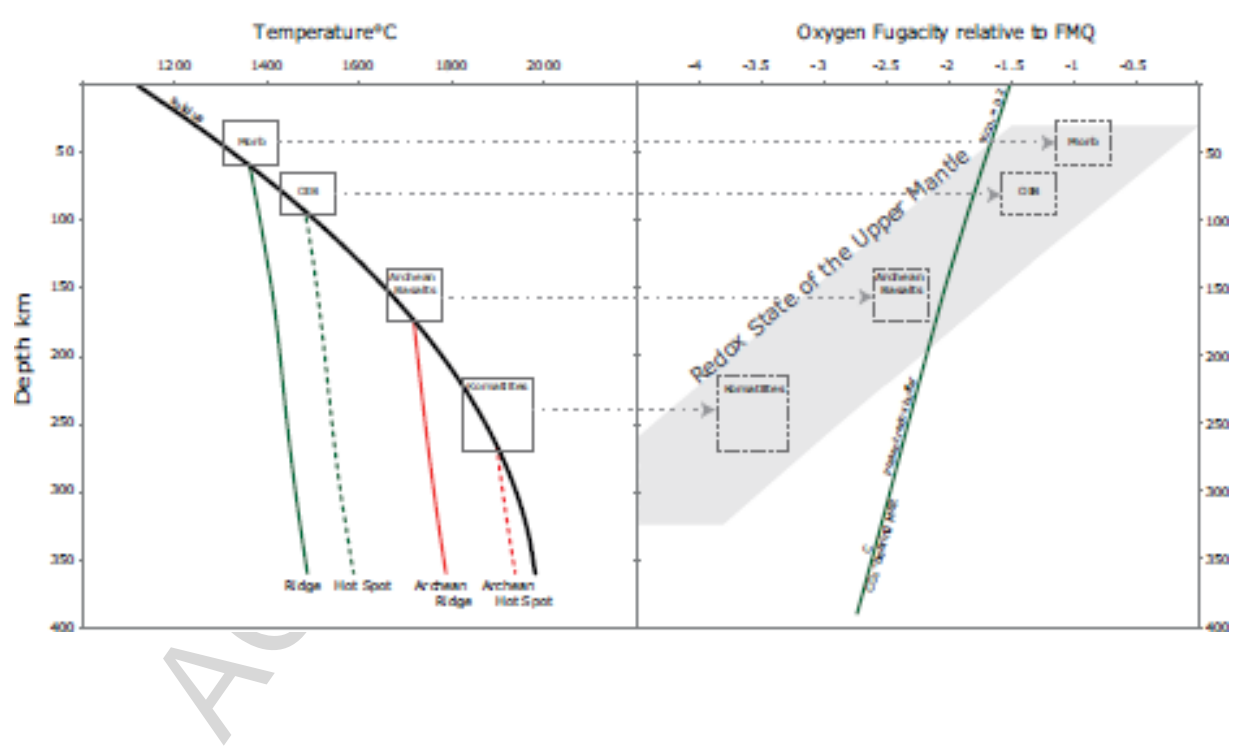




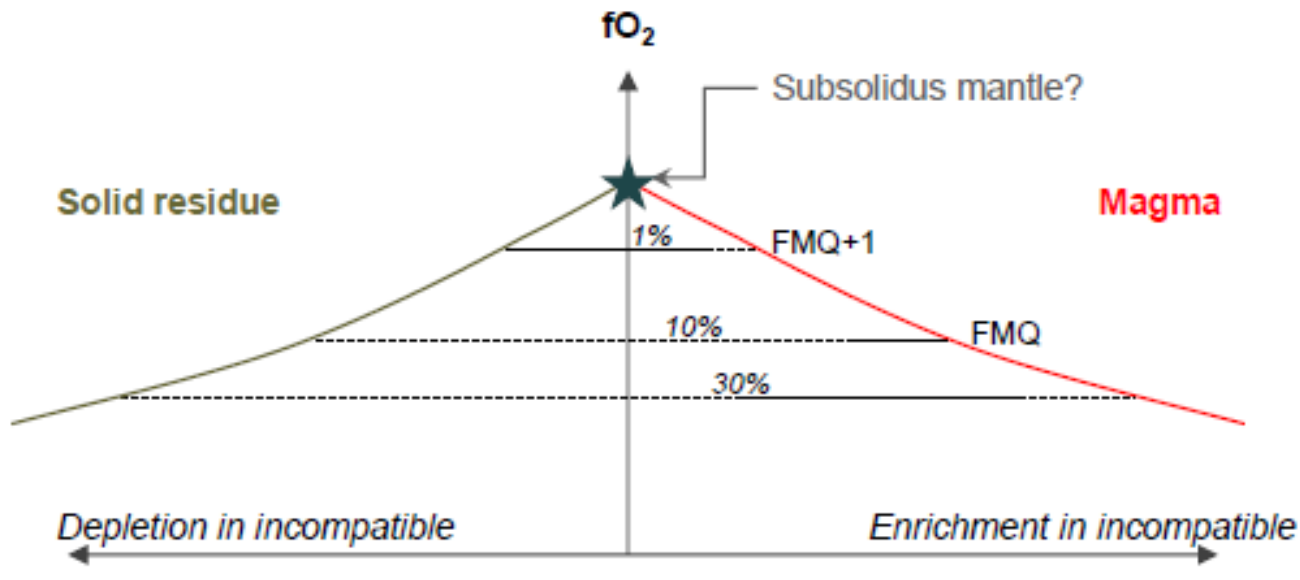


Fig 6

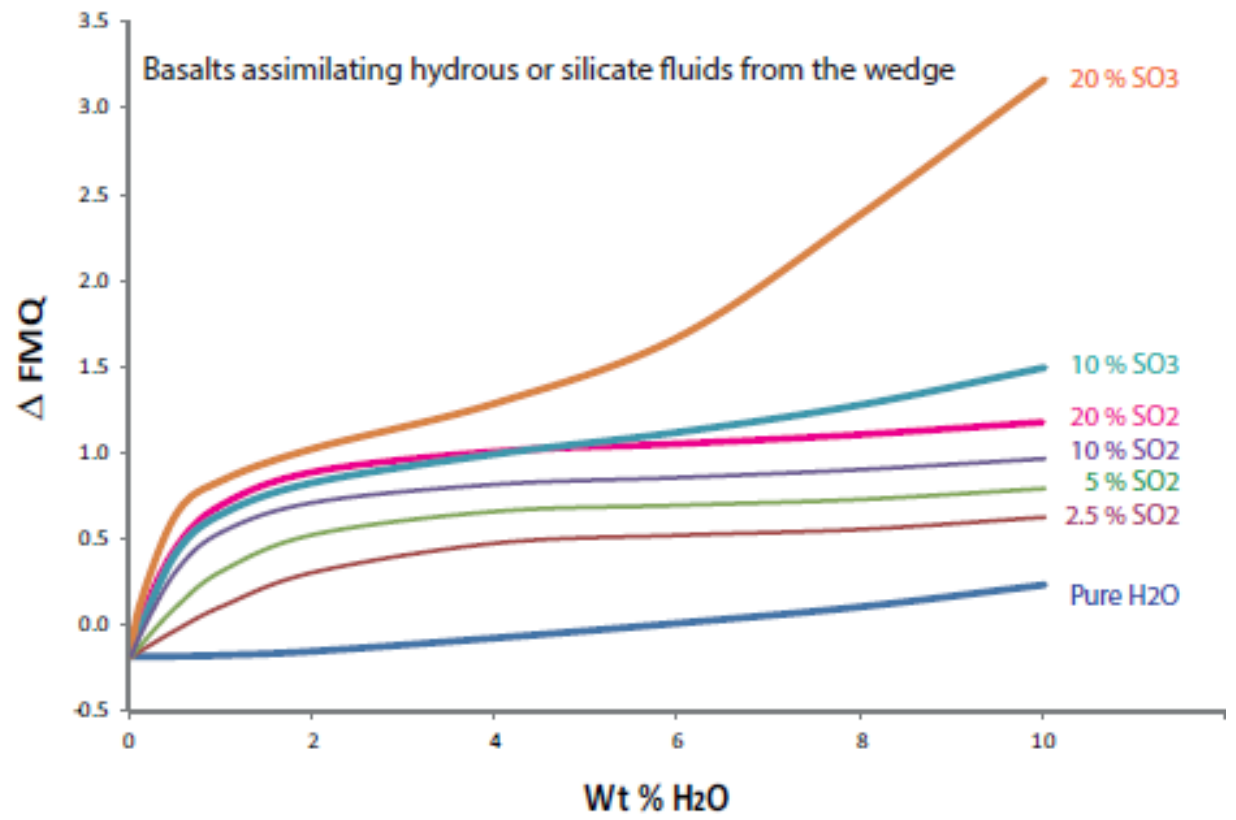


Flgure 7

Oxygen fugacity relative to FMQ

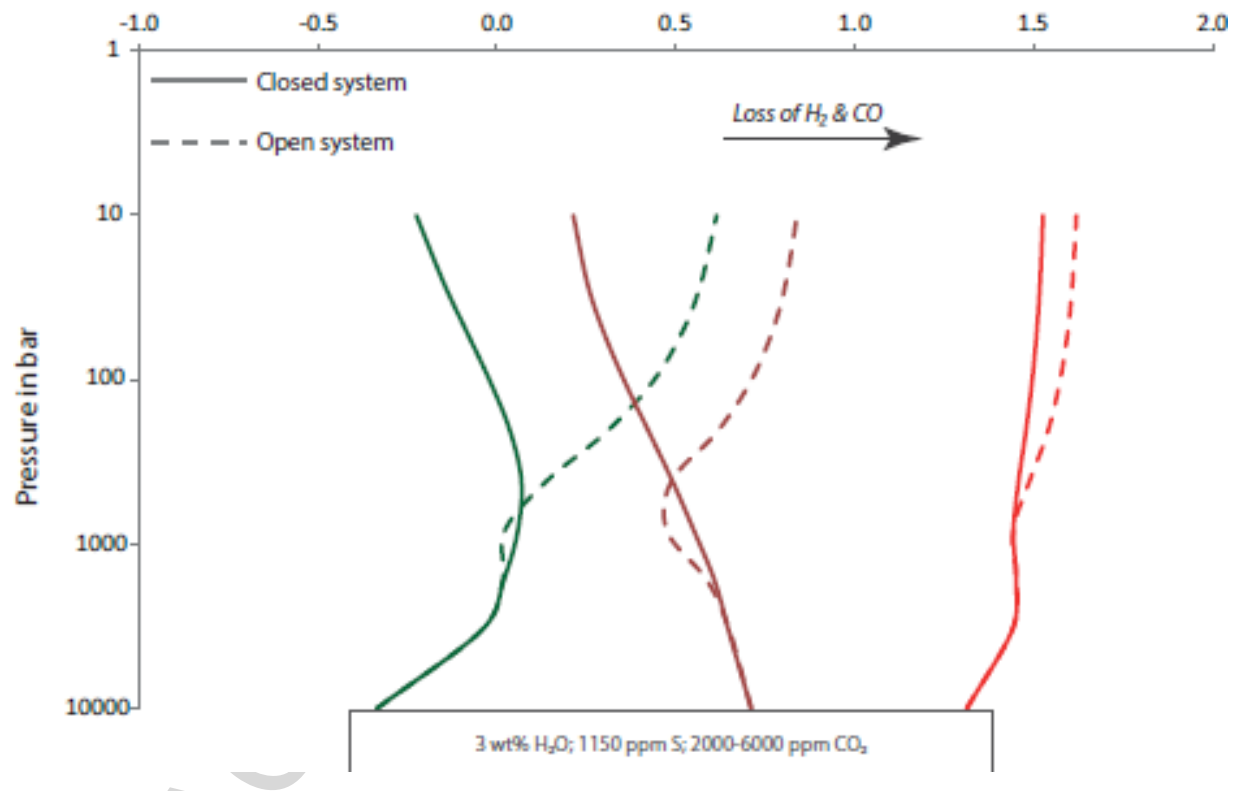


Flgure 8

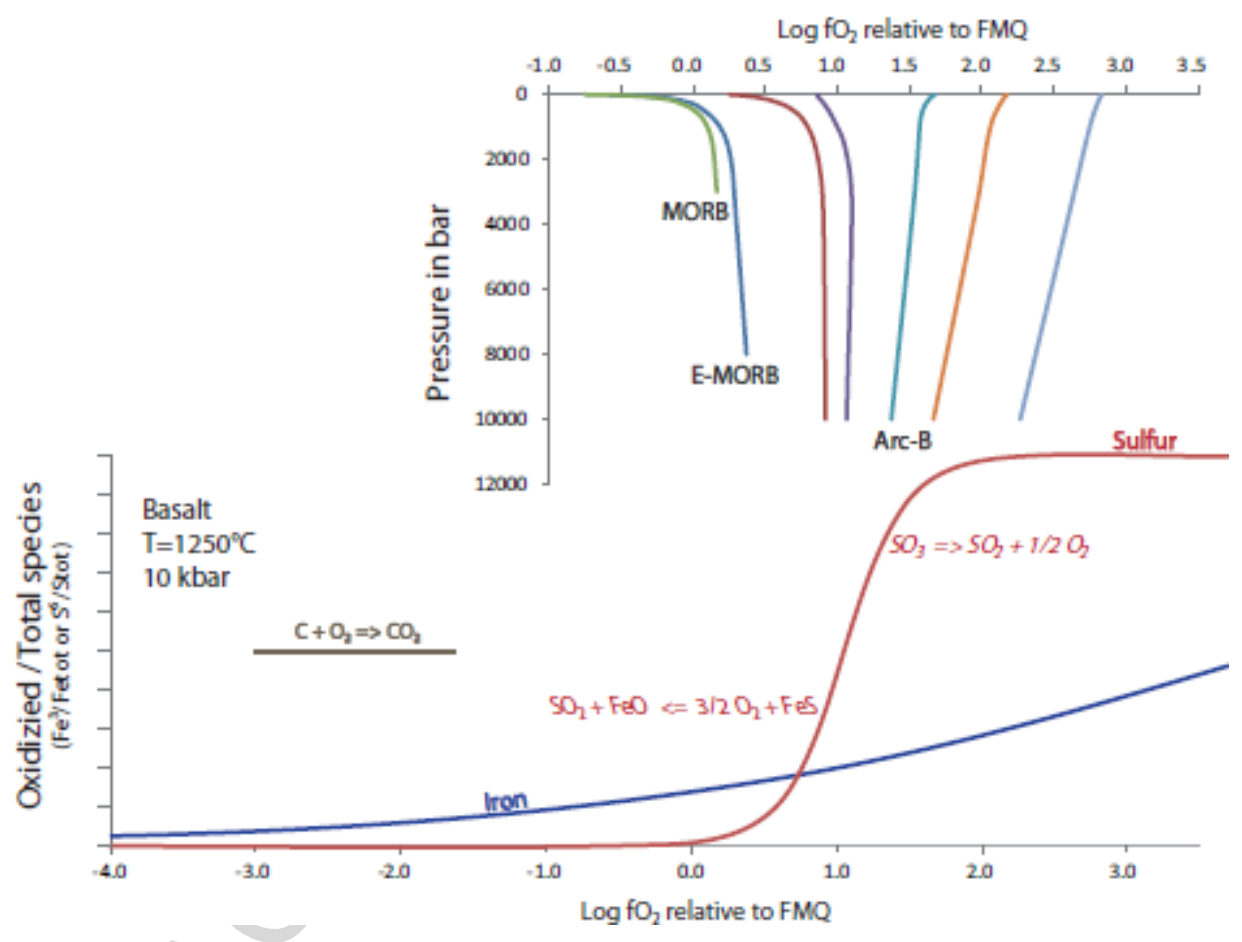


Flgure 9

\section{Redox Geodynamics @ subduction zones}

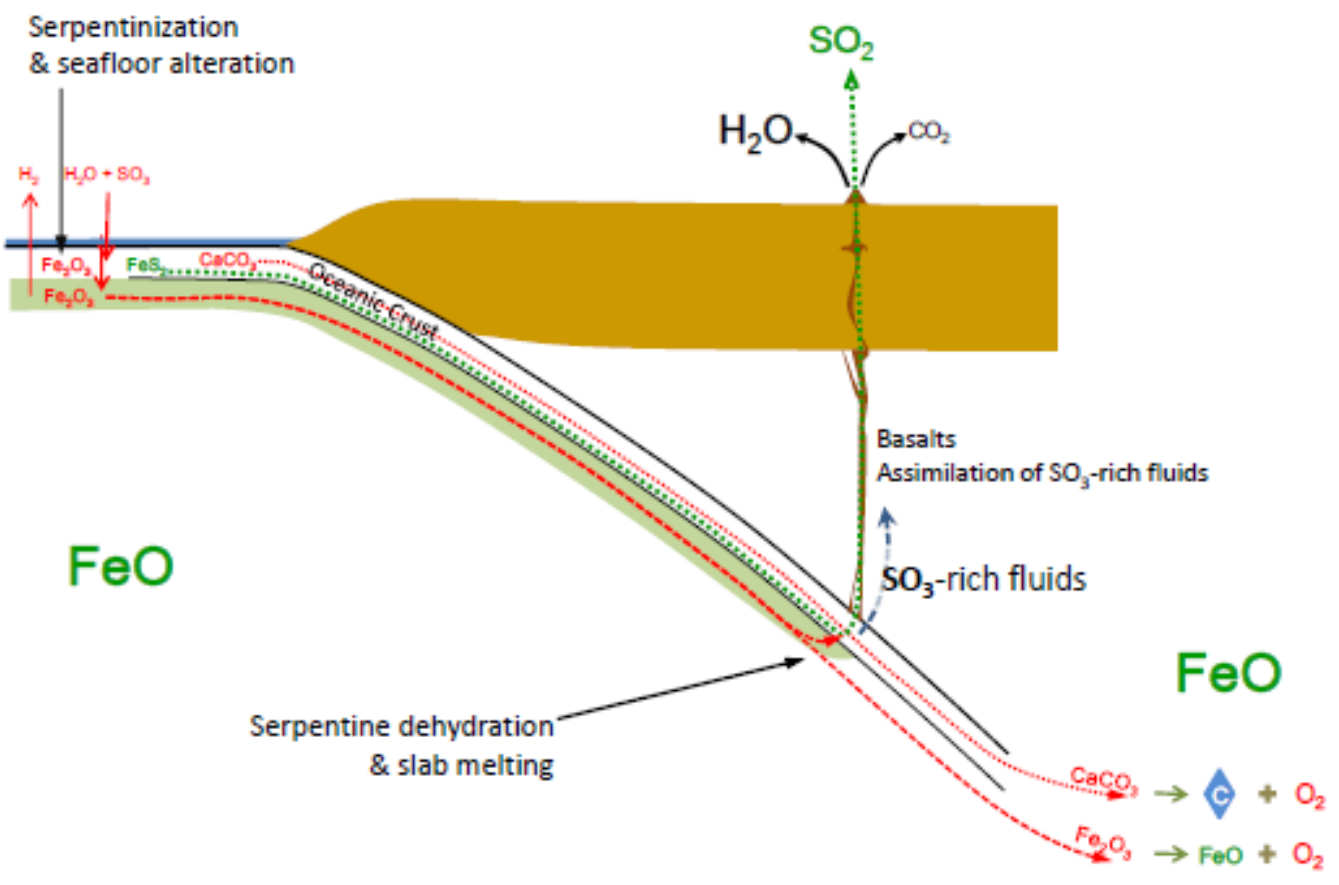

